\title{
Appraisal of the Water Resources of the Big Sioux Aquifer, Lincoln and Union Counties, South Dakota
}

By Colin A. Niehus and Ryan F. Thompson

Water-Resources Investigations Report 97-4161 


\section{U.S. Department of the Interior}

Bruce Babbitt, Secretary

\section{U.S. Geological Survey}

Thomas J. Casadevall, Acting Director

United States Government Printing Office: 1998

For additional information write to:

District Chief

U.S. Geological Survey

1608 Mt. View Road

Rapid City, SD 57702

Copies of this report can be purchased from:

U.S. Geological Survey

Branch of Information Services

Box 25286

Denver, CO 80225-0286 


\section{CONTENTS}

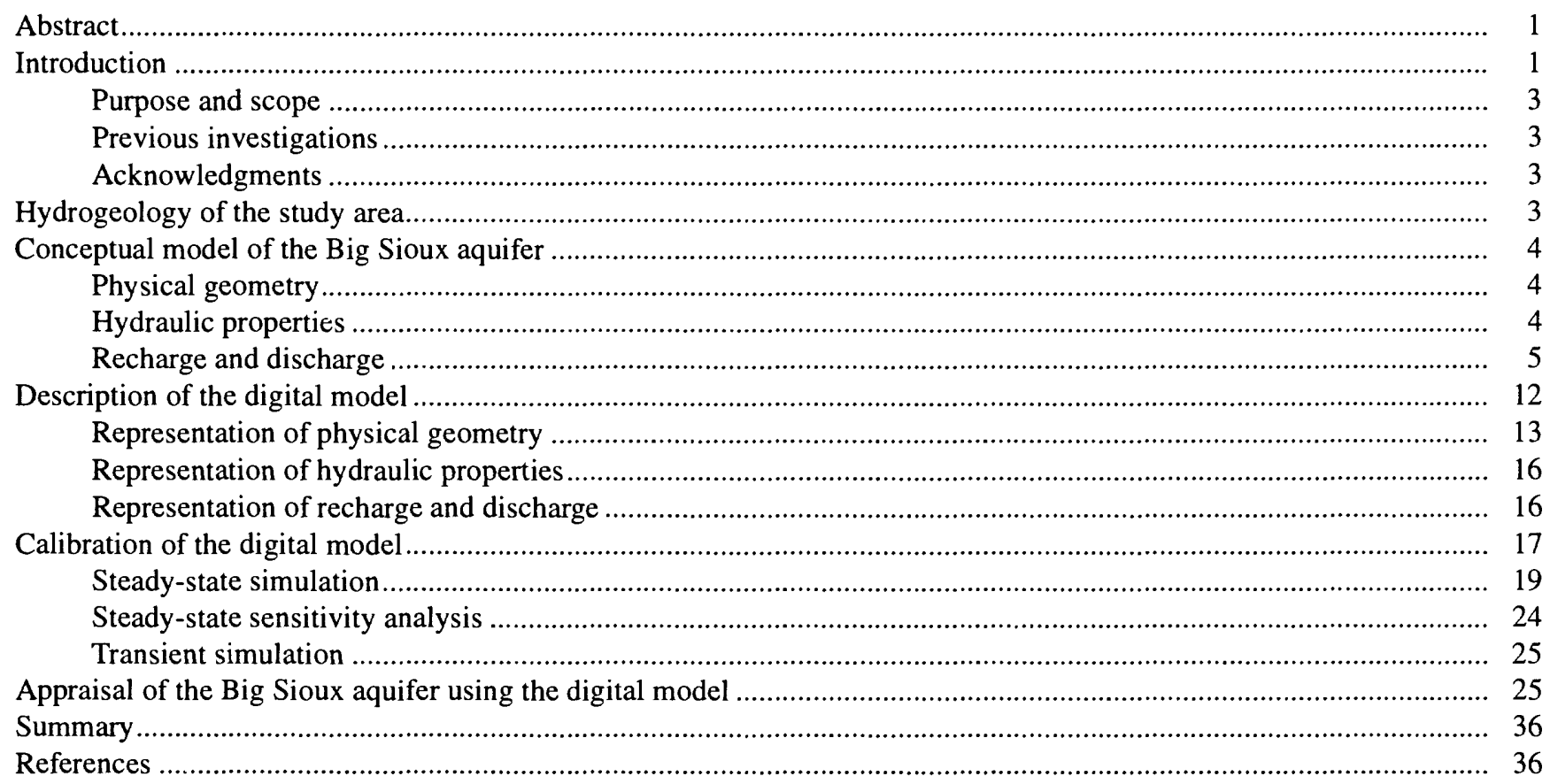

\section{ILLUSTRATIONS}

1. Map showing location of the Big Sioux River Basin, previous study areas, and the study area for this report

2. Map showing extent and thickness of the Big Sioux aquifer

3. Map showing altitude of the bottom of the Big Sioux aquifer

4. Hydrogeologic section A-A' showing the Big Sioux aquifer

5. Graph showing water-level fluctuations in a selected well completed in the Big Sioux aquifer.............................. 10

6. Graph showing cumulative departure from normal precipitation at Canton, S. Dak. ......................................... 11

7. Graph showing ground-water level near, and river stage at Big Sioux River at Akron gaging station.................... 11

8. Map showing model area and boundary conditions represented in the model and location of observation and pumping wells used for steady-state simulation

9. Map showing simulated water-table configuration and difference between simulated and measured water levels, steady-state conditions

10. Map showing simulated transient water-table configuration and differences between simulated and measured water levels at the end of July 1986

11. Hydrographs comparing simulated and measured water levels during the transient simulation. 
1. Pan evaporation for Sioux Falls, S. Dak., and estimated potential evapotranspiration, selected years

2. Average monthly precipitation and estimated recharge

3. Comparison between simulated and measured water levels in the aquifer for steady-state and transient simulations

4. Difference between simulated and measured water levels for steady-state simulation ........................................ 20

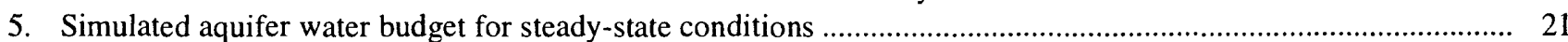

6. Model sensitivity to changes in aquifer hydraulic conductivity, riverbed hydraulic conductivity, maximum evapotranspiration rate, evapotranspiration extinction depth, and recharge rate

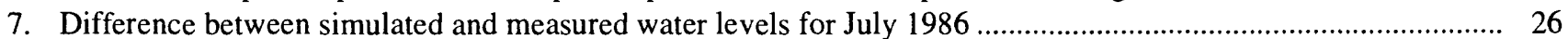

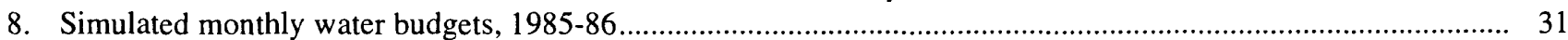

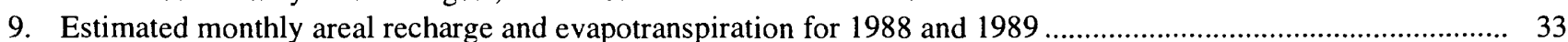

10. Simulated monthly water budgets for 1988 and 1989 with hypothetical increased withdrawals ............................ 34

\section{CONVERSION FACTORS AND VERTICAL DATUM}

\begin{tabular}{|c|c|c|}
\hline Multiply & By & To obtain \\
\hline \multicolumn{3}{|c|}{ Length } \\
\hline inch (in) & 2.54 & centimeter \\
\hline inch (in) & 25.4 & millimeter \\
\hline foot $(f t)$ & 0.3048 & meter \\
\hline mile (mi) & 1.609 & kilometer \\
\hline \multicolumn{3}{|c|}{ Area } \\
\hline acre & 4,047 & square meter \\
\hline acre & 0.4047 & hectare \\
\hline acre & 0.004047 & square kilometer \\
\hline square mile $\left(\mathrm{mi}^{2}\right)$ & 259.0 & hectare \\
\hline square mile $\left(\mathrm{mi}^{2}\right)$ & 2.590 & square kilometer \\
\hline \multicolumn{3}{|c|}{ Volume } \\
\hline acre-foot (acre-ft) & 1,233 & cubic meter \\
\hline acre-foot (acre-ft) & 0.001233 & cubic hectometer \\
\hline \multicolumn{3}{|c|}{ Flow rate } \\
\hline acre-foot per year (acre-ft/yr) & 0.001233 & cubic hectometer per year \\
\hline foot per day (ft/d) & 0.3048 & meter per day \\
\hline foot per mile (ft/mi) & 0.1894 & meter per kilometer \\
\hline cubic foot per second $\left(\mathrm{ft}^{3} / \mathrm{s}\right)$ & 0.02832 & cubic meter per second \\
\hline million gallons per day (Mgal/d) & 0.04381 & cubic meter per second \\
\hline inch per year (in/yr) & 25.4 & millimeter per year \\
\hline
\end{tabular}

Sea level: In this report, "sea level" refers to the National Geodetic Vertical Datum of 1929 (NGVD of 1929)--a geodetic datum derived from a general adjustment of the first-order level nets of both the United States and Canada, formerly called Sea Level Datum of 1929. 


\title{
Appraisal of the Water Resources of the Big Sioux Aquifer, Lincoln and Union Counties, South Dakota
}

\author{
By COLIN A. NIEHUS and RYAN F. THOMPSON
}

\section{ABSTRACT}

The Big Sioux aquifer in Lincoln and Union Counties is a 60 -square-mile, predominantly unconfined aquifer that is hydraulically connected to the Big Sioux River. The aquifer also is hydraulically connected to four glacial aquifers at various locations as follows: to the Shindler aquifer in northeastern Lincoln County, to the Newton Hills aquifer in southeastern Lincoln County, to the Brule Creek aquifer in central Union County, and to the Missouri aquifer in central Union County. The average thickness of the Big Sioux aquifer in Lincoln and Union Counties is 28 feet, and its maximum thickness is 72 feet. The aquifer is overlain by either alluvium/colluvium or till and underlain by mostly till or Carlile Shale.

A digital model was constructed to simulate ground-water flow in the Big Sioux aquifer in Lincoln and Union Counties. The Shindler, Newton Hills, Brule Creek, and Missouri aquifers were treated as various boundary conditions to simulate hydraulic connections to the Big Sioux aquifer. The model was calibrated to simulate both steady-state (1976-94) and transient (1985 and 1986) conditions. The model was calibrated for steady-state conditions using average annual water levels of the Big Sioux aquifer, recharge, evapotranspiration, well pumpage, river stages, and base-flow discharge in the Big Sioux River. Steady-state simulated water levels for the Big Sioux aquifer from 57 observation wells averaged 0.91 foot lower than measured water levels. The average absolute difference between simulated and measured water levels was 1.54 feet.

The model was calibrated for transient conditions using 1985 and 1986 ground-water levels in as many as 62 observation wells on a monthly basis. The average monthly difference between simulated and measured water levels was -0.15 foot. The absolute value of the average monthly difference between simulated and measured water levels was 1.76 feet.

A hypothetical simulation using dryer than normal conditions and maximum sustainable irrigation pumpage was run to evaluate management practices and to aid in prudent utilization of water from the Big Sioux aquifer in Lincoln and Union Counties. The simulation revealed that the Big Sioux aquifer was unable to support continuous pumpage at the current permitted irrigation pumping rates in Lincoln and Union Counties.

\section{INTRODUCTION}

The Big Sioux River Basin has a drainage area of about 9,000 $\mathrm{mi}^{2}$ (Amundson and others, 1985) in eastern South Dakota, southwestern Minnesota, and northwestern Iowa (fig. 1). The basin is approximately $210 \mathrm{mi}$ long and $65 \mathrm{mi}$ wide at its widest sections. In South Dakota, the basin extends from southern Marshall to southern Union County. The Big Sioux aquifer in Lincoln and Union Counties is a glacialoutwash aquifer extending the entire length of the Big Sioux River and coincident mostly to its flood plain. 


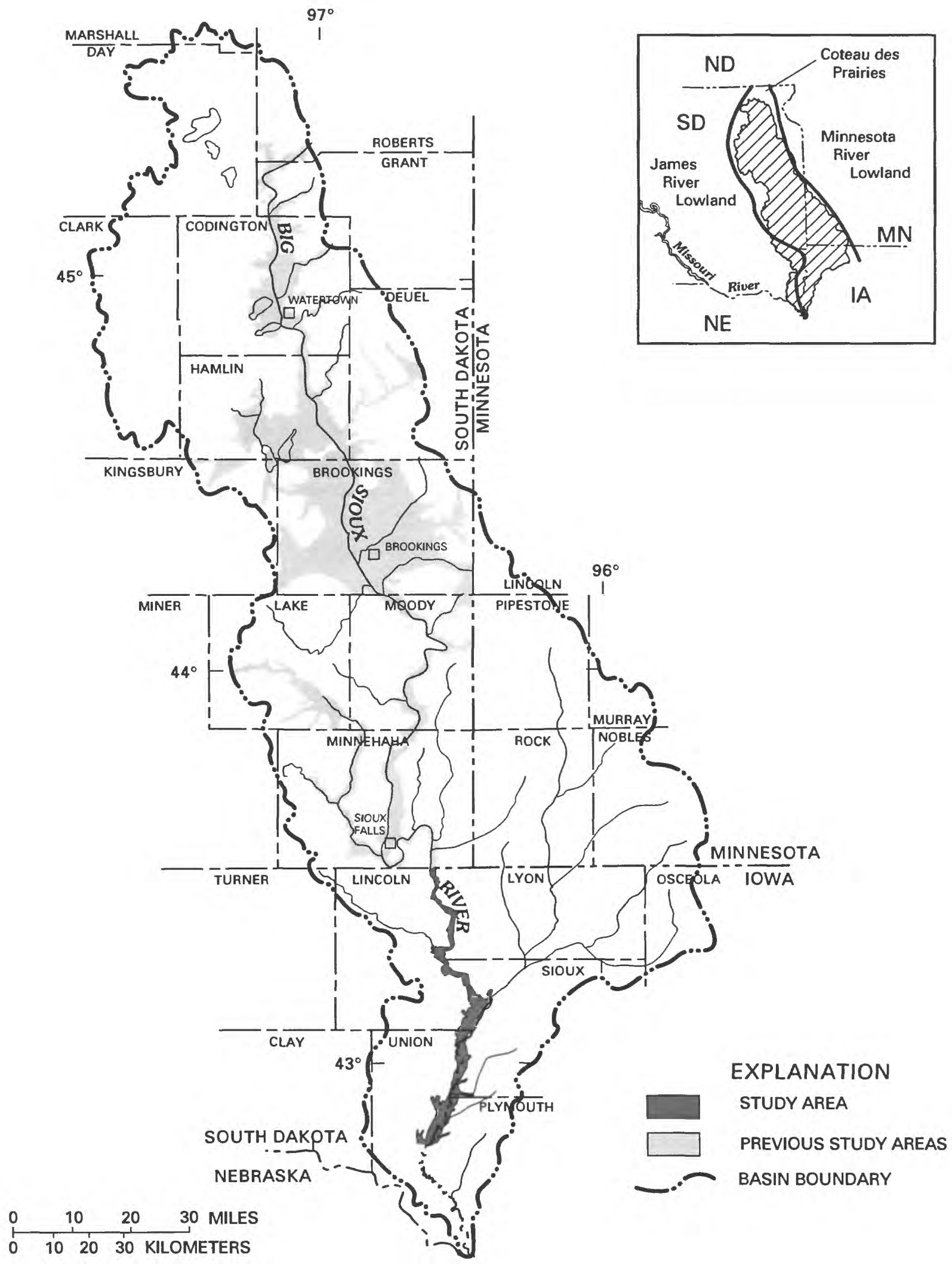

Figure 1. Location of the Big Sioux River Basin, previous study areas, and the study area for this report. 
The Big Sioux Hydrology Study began in 1982 and includes a comprehensive county-by-county investigation of the water resources within the basin. The purpose of the study is to provide hydrogeologic information and analytical tools needed for effective management of the ground-water resources in the Big Sioux River Basin. This was to be achieved through the development of a series of digital-computer models . of the Big Sioux aquifer. Each of the models was developed using a consistent set of techniques to be compatible with other models in the Big Sioux Hydrology Study. The study described in this report was a cooperative effort between the U.S. Geological Survey, the South Dakota Geological Survey, and Lincoln and Union Counties.

\section{Purpose and Scope}

This report is the product of a 4-year (1985-88) water-resources investigation and describes model development for the Big Sioux aquifer (fig. 1). The model was constructed to be used as a tool to analyze the hydrologic system and to provide an improved, quantitative understanding of the system. The model was used to evaluate the effects of hypothetical drought stresses and additional irrigation pumpage on water levels in the Big Sioux aquifer and on streamflows of the Big Sioux River. These stresses include decreased precipitation, increased evapotranspiration, and decreased streamflow.

The model area was extended one-half mile north into Minnehaha County to minimize boundary effects in Lincoln County and into Iowa to adequately simulate natural boundaries and river-aquifer interactions. The Big Sioux aquifer on the Iowa side of the Big Sioux River has not been studied at the same detail as it has on the South Dakota side. Therefore, that portion of the model on the Iowa side was not developed to predict water levels in the Big Sioux aquifer in Iowa. Rather, observation-well data on the Iowa side were used to ensure that simulated water levels adequately reflect the ground-water/surface-water interactions between the Big Sioux aquifer and the Big Sioux River.

\section{Previous Investigations}

Other work completed in the study area includes evaluation of sand and gravel deposits in Lincoln County (Schulz and Jarrett, 1991) and in Union County
(Jarrett, 1988). Niehus (1994) investigated the water resources in Lincoln and Union Counties. The major aquifers in Lincoln and Union Counties have recently been described (Niehus, 1997). Iles (1979) conducted a ground-water study for southern Union County in the region of McCook Lake and adjacent communities. Investigations in counties adjacent to the study area include a water-resources investigation of Minnehaha County (Lindgren and Niehus, 1992), and a model of the Big Sioux aquifer in Minnehaha County to investigate depletion of the aquifer under drought conditions and increased pumping rates (Koch, 1982). The geology of Minnehaha County has recently been described by Tomhave (1994). The geology and hydrology of Clay County were explored by Christensen and Stephens (1967). The sand and gravel resources of Turner County have been documented by Jarrett (1986), and Lindgren and Hansen have explored the water resources of Hutchinson and Turner Counties (1990) and major aquifers in Hutchinson and Turner Counties (1993). The delineation of drainage areas in the Big Sioux River Basin was completed by Amundson and others (1985), and those in the adjacent Vermillion River Basin by Benson and others (1988).

\section{Acknowledgments}

The authors acknowledge the cooperation of residents and municipal officials of Lincoln and Union Counties for providing information concerning the water wells they own or manage. The South Dakota Geological Survey drilled test holes and installed observation wells for this project. Test-hole information provided by local drilling companies also was used for this study and is appreciated. The authors also want to thank the Iowa Geological Survey for information on test holes and observation wells in Iowa, and Ed Fischer of the U.S. Geological Survey, Iowa District, for water-use data in Iowa.

\section{HYDROGEOLOGY OF THE STUDY AREA}

Extreme northern and southeastern Lincoln County and eastern Union County are within the Coteau des Prairies, a highland plateau between the Minnesota River Lowland to the east and the James River Lowland to the west (fig. 1). Central Lincoln County and part of western Union County lie in the eastern part of the James River lowland. Southern 
Union County lies within the Missouri River trench. The Coteau des Prairies is composed of bedrock formations overlain by unconsolidated glacial outwash and till. Lincoln and Union Counties are primarily overlain by Pleistocene glacial deposits with a smaller amount of non-glacial loess and river deposits (Niehus, 1994). The glacial deposits are either till or outwash. Several bedrock units underlie the glacial deposits, non-glacial loess, and river deposits in the study area. In ascending order, the bedrock units in Lincoln and Union Counties include Precambrian Sioux Quartzite and Sioux Quartzite wash, Paleozoic sandstones, and of Cretaceous age, the Dakota Formation, Graneros Shale, Greenhorn Limestone, Carlile Shale, Niobrara Formation, and Split Rock Creek Formation (Hammond, 1989).

The drainage in eastern and northern Lincoln County and most of Union County is well developed and is primarily through the Big Sioux River, which flows from north to south, and its tributaries. East of the Big Sioux River in Iowa, drainage is primarily by the Rock River, which is the largest tributary of the Big Sioux River within the study area. Streamflow depends on seasonal variations in precipitation, evapotranspiration, and ground-water storage. Creeks generally flow during spring and early summer because of snowmelt and rainfall runoff, and because storage in aquifers is at a peak. Creeks generally do not flow during late summer through winter because of limited direct runoff and decreased ground-water discharge, and increased evapotranspiration in summer. The general direction of lateral water movement in the Big Sioux aquifer is to the south and locally towards the Big Sioux River.

The materials that comprise the Big Sioux aquifer in Lincoln and Union Counties range from fine sand to very coarse gravel. The aquifer is connected hydraulically with the Shindler aquifer (T. 98 N., Rs. 48 and 49 W.); Newton Hills aquifer (Tps. 97 and 98 N., Rs. 48 and 49 W.); Missouri aquifer (T. 92 N., R. 49 W.); and the Big Sioux River. Water-level analysis indicates that leakage occurs through sandy till from the Brule Creek aquifer (T. 96 N., R. 49 W.). Water-level analysis also indicates an inflow of water in T. 93 N., R. 48 W., probably from the outwash/ alluvial valleys of small tributaries of the Big Sioux River. A further explanation of the adjacent aquifers in the study area is available in Niehus (1994).

\section{CONCEPTUAL MODEL OF THE BIG SIOUX AQUIFER}

Before a ground-water system may be modeled, there must be a basic understanding of its nature. The various aspects of the system must be known well enough to ensure that they are adequately represented in the model. The physical geometry, hydraulic properties, and recharge-discharge relations are discussed in the following sections.

\section{Physical Geometry}

Well and test-hole data for Lincoln and Union Counties in South Dakota, and parts of Lyon, Sioux, and Plymouth Counties in Iowa, were obtained from the South Dakota Geological Survey, private drillers, and other sources. The well and test-hole data provided information on the thickness and extent (fig. 2), depth, and composition of the aquifer and overlying material. The extent of the Big Sioux aquifer in this study is based on that used by Niehus (1994), with some modifications by R.H. Hammond (South Dakota Geological Survey, oral commun., March 1998). The Big Sioux aquifer underlies approximately $60 \mathrm{mi}^{2}$ of Lincoln and Union Counties and is located primarily in the flood plain of the Big Sioux River. In Lincoln and Union Counties, it has a maximum thickness of $72 \mathrm{ft}$ and an average thickness of $28 \mathrm{ft}$ (Niehus, 1994). A test hole located in the Big Sioux aquifer in Iowa has a thickness of $77 \mathrm{ft}$. The average thickness of the aquifer is about $25 \mathrm{ft}$ when test-hole data from the adjacent Iowa counties are included. The aquifer is primarily unconfined and is overlain by alluvium/colluvium or till and underlain by till or Carlile Shale. The average depth to the top of the aquifer material below land surface is $12 \mathrm{ft}$, and the average thickness of the saturated zone is $13 \mathrm{ft}$ (Niehus, 1994). The altitude of the bottom of the aquifer was determined from drillers' logs of wells and test holes within the study area (fig. 3). The altitude of the aquifer bottom within the study area ranges from 1,038 to $1,254 \mathrm{ft}$ above sea level. A generalized hydrogeologic section is shown in fig. 4 .

\section{Hydraulic Properties}

Transmissivity is the product of hydraulic conductivity and saturated thickness. Hydraulic conductivity is the rate of flow of water through a unit cross-sectional area under a unit hydraulic gradient. Twenty aquifer tests have been conducted in the Big 
Sioux aquifer in Moody, Brookings, and Minnehaha Counties (Ellis and Adolphson, 1969; Koch, 1980). Pumping tests conducted on 35 wells in the Sioux Falls city well field yielded transmissivity and saturated thickness values from which hydraulic conductivity could be determined. Most hydraulic conductivity values were within the range of 300 to $800 \mathrm{ft} /$ day. Because the sediments south of Sioux Falls were deposited by the same glacial event and in a similar manner, the hydraulic conductivity values in the study area could be within a similar range. However, since many of the tests were conducted on production wells within the Sioux Falls City well field, well development procedures may have affected these hydraulic conductivities. Extensive development of the gravel pack around a well could lead to higher hydraulic conductivities than in areas with undisturbed aquifer materials.

The storage coefficient represents the volume of water that an aquifer releases from or takes into storage from a unit surface area of the aquifer per unit change in head. For unconfined aquifers, the storage coefficient is dominated by specific yield, which represents the draining or filling of the pore space in the soil matrix. Koch (1980) reported specific yields ranging from 0.10 to 0.17 from four aquifer tests conducted in the Big Sioux aquifer in Brookings, Deuel, and Hamlin Counties. Koch chose specific yields of 0.10 (1980) and 0.20 (1982) in modeling other areas of the Big Sioux aquifer. Hansen (1988) also used a specific yield of 0.20 to model the Big Sioux aquifer in Moody County. The specific yield of the Big Sioux aquifer in Codington and Grant Counties was computed using the neutron method (Meyer, 1962; Jones and Schneider, 1969). A neutron moisture probe was used to measure moisture contents at nine locations after water-level changes. The range of specific yields from this method was from 0.10 to 0.17 . Putnam and Thompson used a specific yield of 0.14 to model the aquifer in this area. Ohland (1990) used a specific yield of 0.20 to model the Skunk Creek aquifer, which lies adjacent to and west of the Big Sioux aquifer in Minnehaha County. An average specific yield of 0.20 was used in this study based on Koch (1982), Hansen (1988), and Ohland (1990).

Riverbed hydraulic conductivity affects the movement of water between the aquifer and the Big Sioux River. Jorgensen and Ackroyd (1973) determined that riverbed hydraulic conductivities ranged from 0.5 to $1.0 \mathrm{ft} / \mathrm{d}$, based on three aquifer tests in the Big Sioux aquifer in Minnehaha County. In some areas of limited aquifer thickness, the river may have scoured through the aquifer material to the underlying till. An area exists south of Canton where, according to drillers' logs, the aquifer material is as little as $2 \mathrm{ft}$ thick, and there the riverbed hydraulic conductivity probably is substantially lower than the values given above.

\section{Recharge and Discharge}

Recharge to the aquifer is mostly by infiltration and subsequent downward percolation of rainfall and snowmelt (areal recharge) in areas where the aquifer is near land surface, and by lateral ground-water discharge from the Shindler aquifer in northeastern Lincoln County and the Newton Hills aquifer in southeastern Lincoln County. Another probable source of recharge is lateral flow through sandy till from the Brule Creek aquifer in T. 96 N. in southern Lincoln County (Niehus, 1994), and from alluvial outwash valleys in T. $93 \mathrm{~N}$. in central Union County. Although water levels in the aquifer immediately adjacent to the Big Sioux River may fluctuate in direct response to rises in the stage of the river, this bank storage is transient and returns to the river soon after the stage returns to normal. The aquifer also may gain from the river in areas where pumping wells are near the river, causing the river to lose water to a drawdown cone. Flow also may be induced to the aquifer from the river to satisfy small, localized water-table depressions caused by evapotranspiration by plants (especially trees) in topographically low areas.

Records of water-level fluctuations in well 99N48W32DCDD (fig. 5) exemplify general correspondence with trends in precipitation (fig. 6). Waterlevel rises generally correspond with above-normal precipitation, and water-level declines correspond with below-normal precipitation. Seasonally, water levels generally rise from February through June because recharge from snowmelt and spring rainfall is greater than discharge (Hansen, 1990). Water levels generally decline from July through January because discharge from wells, discharge to rivers, and evapotranspiration during the summer and early fall are greater than recharge. By comparing water levels in observation well 93N48W30CCAC with stages on the Big Sioux River near Akron, it is evident that the aquifer generally loses water to the river at that location (fig. 7). A similar relation between the aquifer and river is assumed to occur throughout the study area. 


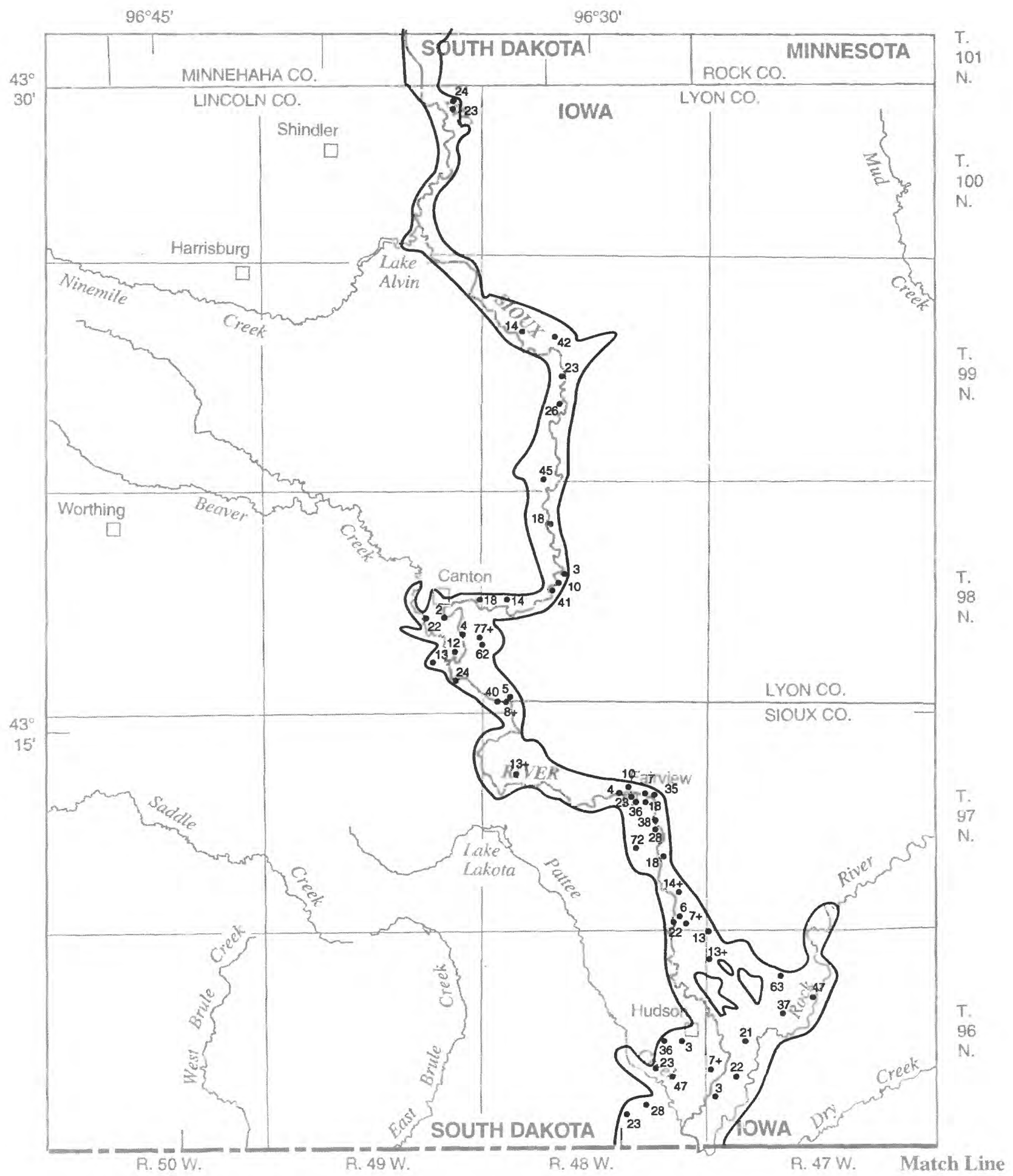

Figure 2. Extent and thickness of the Big Sioux aquifer. 


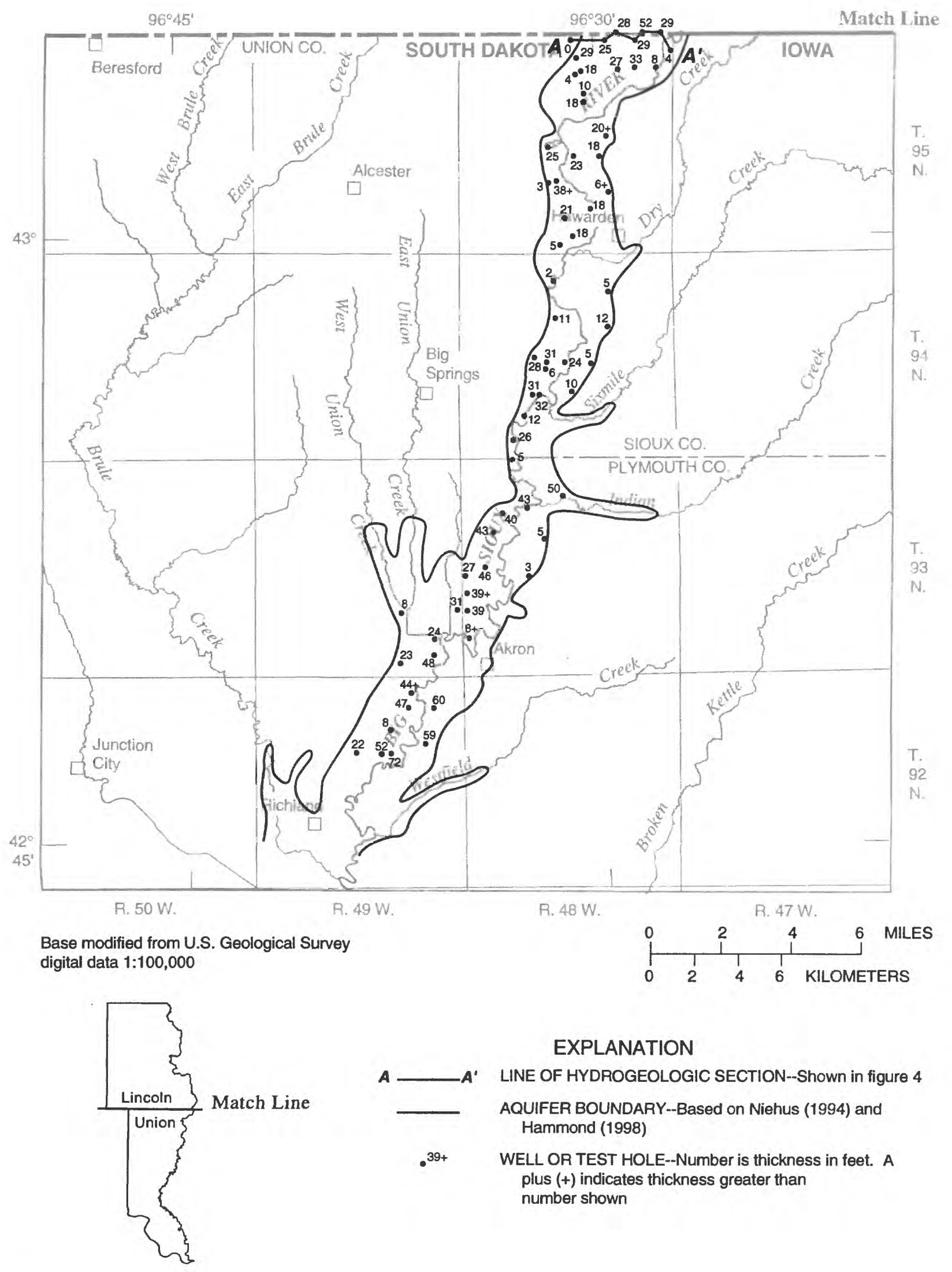

Figure 2. Extent and thickness of the Big Sioux aquifer.--Continued 


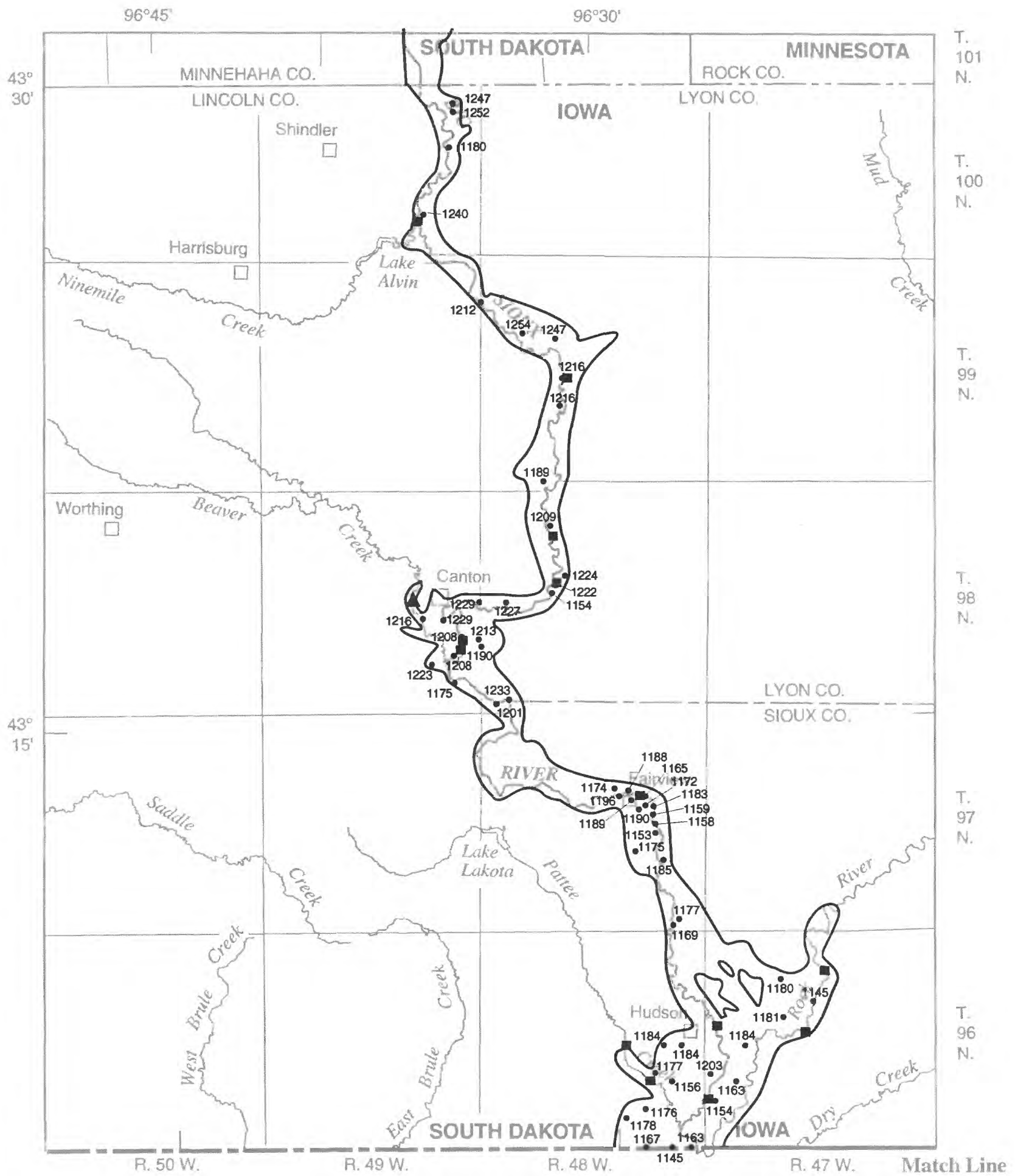

Figure 3. Altitude of the bottom of the Big Sioux aquifer. 


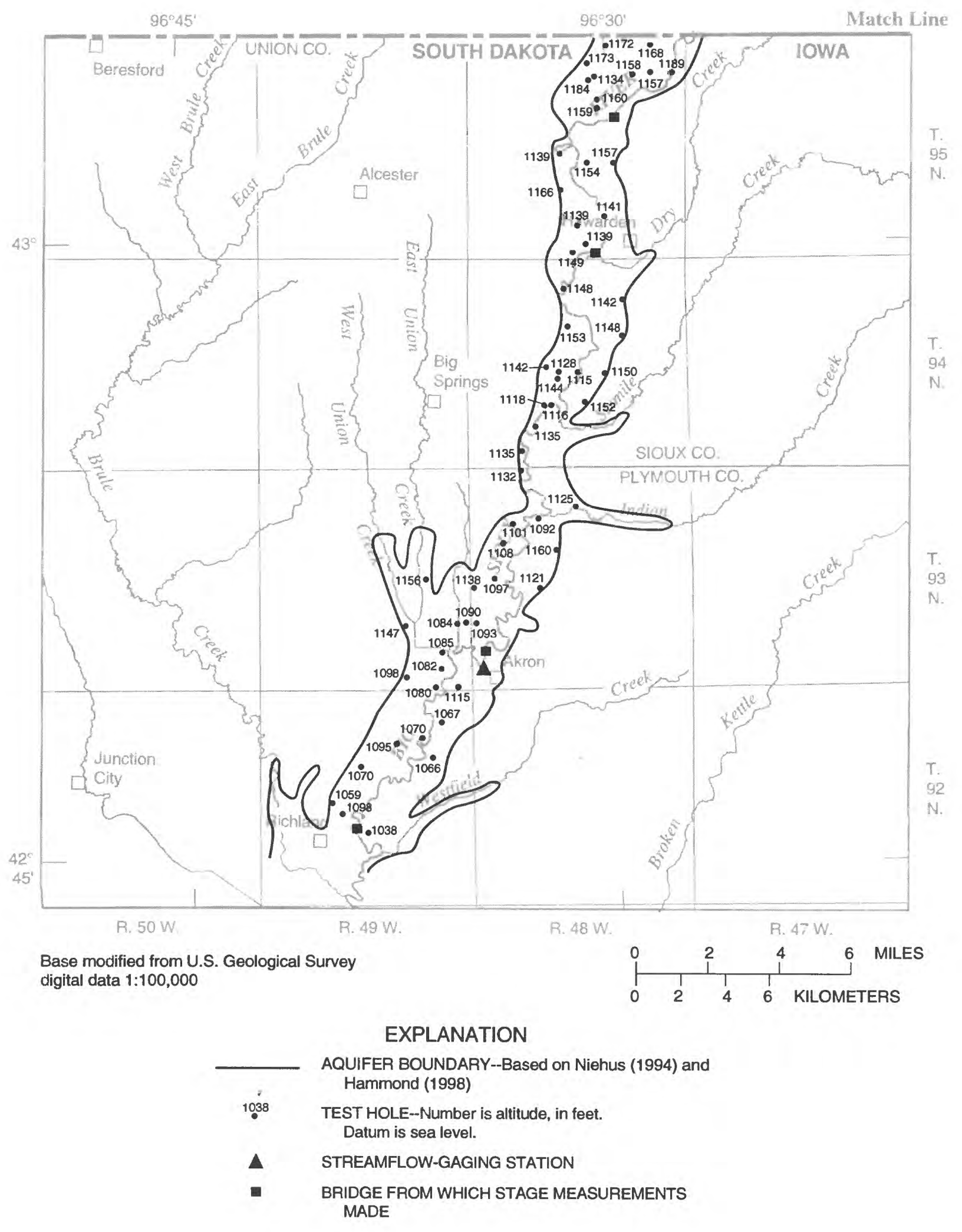

Figure 3. Altitude of the bottom of the Big Sioux aquifer.--Continued 


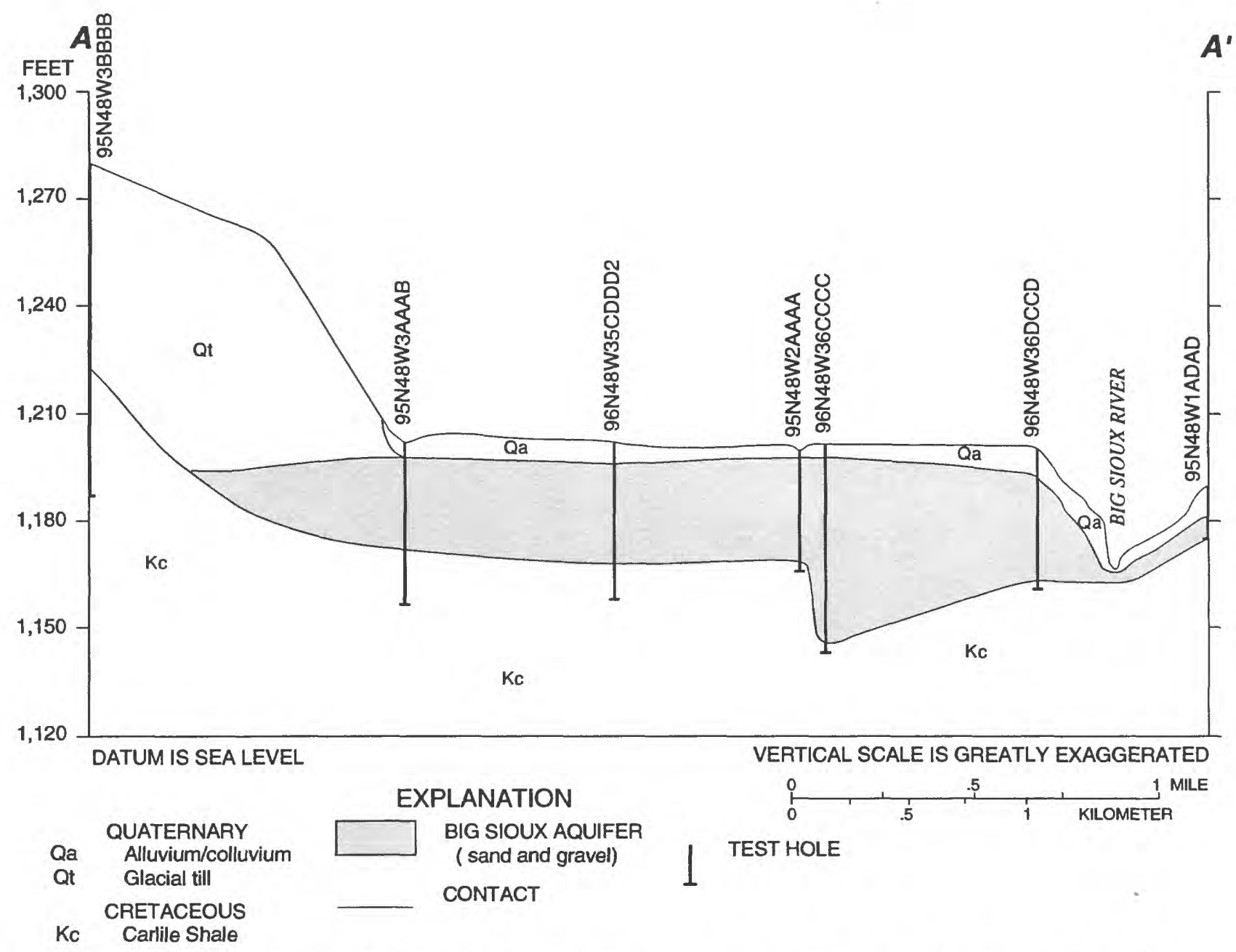

Figure 4. Hydrogeologic section A-A' showing the Big Sioux aquifer. (Location of section A-A' is shown in fig. 2.)

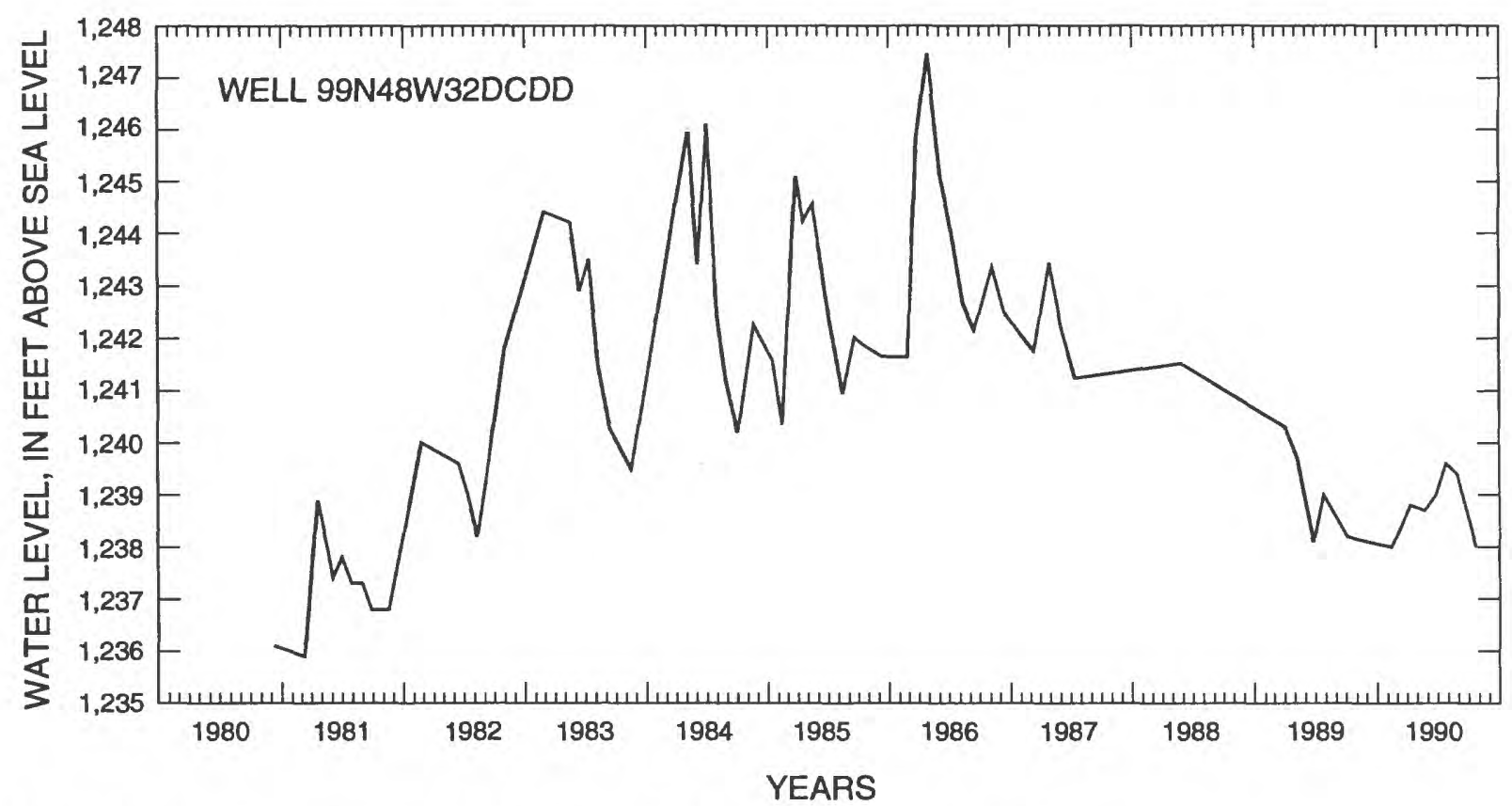

Figure 5. Water-level fluctuations in a selected well completed in the Big Sioux aquifer. 


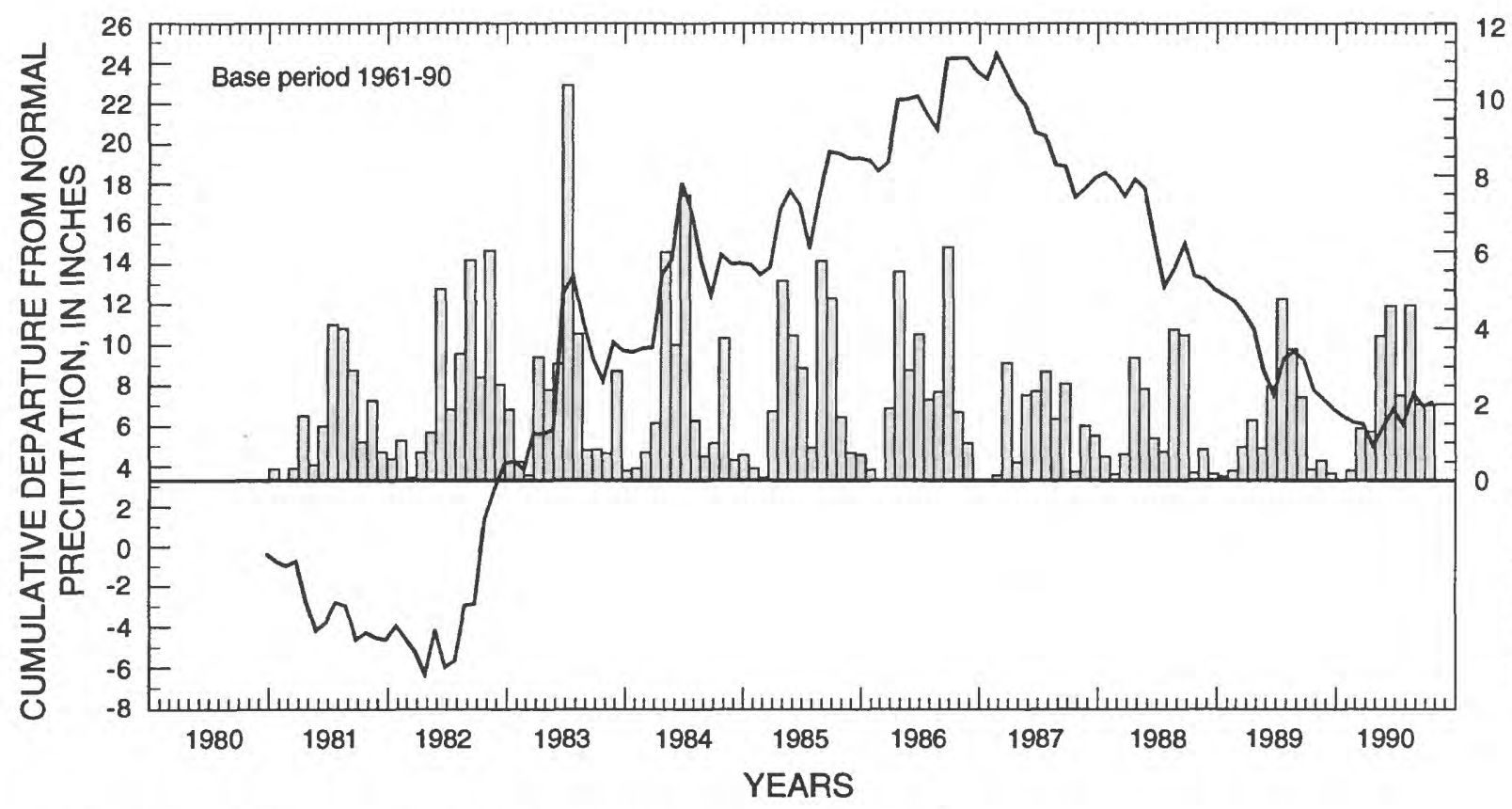

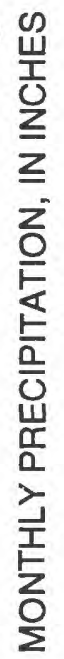

Figure 6. Cumulative departure from normal precipitation at Canton, S. Dak.

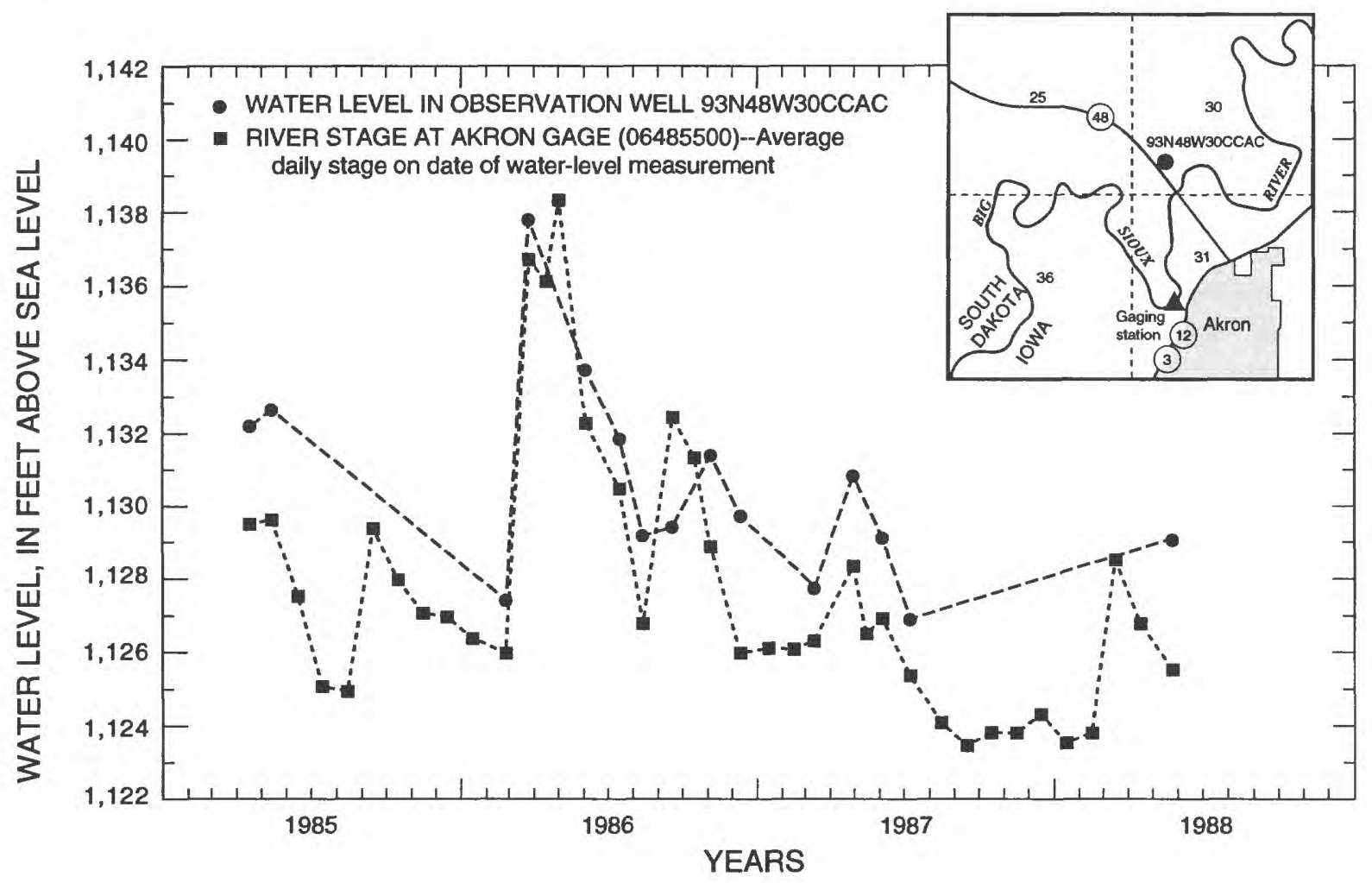

Figure 7. Ground-water level near, and river stage at Big Sioux River at Akron gaging station. 
Annual precipitation over the study area was taken as the average of the precipitation measured at Centerville (west of Lincoln County in southeastern Turner County) and Canton (fig. 2) weather stations, which was $24.3 \mathrm{in}$. for 1961-90. The period 1976-94 had a slightly greater than average precipitation of $25.2 \mathrm{in} / \mathrm{yr}$ (approximately 4 percent greater), but the overall conditions during this period were assumed to reflect long-term average conditions.

Hansen (1990) found that only 10 to 20 percent of precipitation percolated past the root zone to reach the Big Sioux aquifer in Codington and Grant Counties. During much of the year, recharge is inversely related to monthly pan evaporation, and reflects moisture captured by vegetation during the growing cycle. Recharge to the aquifer is negligible in the winter months when the ground is frozen.

Recharge rates are high during early spring, because snowmelt and heavy precipitation occur and evapotranspiration is low. At this time, crops are unplanted or beginning the growth cycle. Later in spring, warmer weather and developing plant cover increase evapotranspiration and decrease recharge. As summer begins, evapotranspiration and plant growth continue to increase and recharge decreases. In September and October, as crops mature and growth cycles end, evapotranspiration decreases and recharge increases.

A range of potential recharge was estimated from water-level rises in observation wells located at least one-quarter mile from the river and thought to be unaffected by pumping wells. At this distance, possible errors introduced by bank storage are assumed to be minimized. Fourteen observation wells were identified and averaged $3.14 \mathrm{ft}$ of water-level rise per year in the years with monthly measurements. The water-level rise ranged from 0.89 to $5.40 \mathrm{ft} / \mathrm{yr}$. Using a specific yield of 0.20 , the estimated recharge rate for the Big Sioux aquifer averaged $7.54 \mathrm{in} / \mathrm{yr}$ and ranged from 2.14 to $12.96 \mathrm{in} / \mathrm{yr}$.

Discharge from the Big Sioux aquifer is by evapotranspiration; base flow to the Big Sioux River and its tributaries within the aquifer extent; leakage to the Missouri aquifer; and pumping from irrigation, municipal, rural-water-system, domestic, and stock wells.

The pan evaporation rate was assumed to be a good indicator of the potential evapotranspiration rate (Eagleman, 1967). The estimated potential evapotranspiration was calculated by assuming that the pan evaporation was directly proportional to this potential evapotranspiration. The average annual pan evaporation was $53.4 \mathrm{in} / \mathrm{yr}$ (National Oceanic and Atmospheric Administration, 1976-94). The potential evapotranspiration in the study area is estimated to be about 74 percent of the pan evaporation (National Oceanic and Atmospheric Administration, 1982b), or about $39.4 \mathrm{in} / \mathrm{yr}$. The average monthly pan evaporation and estimated potential evapotranspiration rates are shown in table 1.

The average annual base flow from the Big Sioux aquifer to the Big Sioux River was estimated using data from streamflow-gaging stations on the Big Sioux River. Precipitation was near normal in the study area during calendar year 1990 , so the average flows for that year were used. Flows from the streamflow-gaging stations at North Cliff Avenue at Sioux Falls, Split Rock Creek at Corson, Beaver Creek at Canton, and Rock River near Rock Valley, Iowa, were subtracted from the flow at the gaging station at Akron, Iowa. The Split Rock Creek and Beaver Creek gages were not active during 1990, so the median of the 24 yearly means, and the average of the 7-year period of record, respectively, were used. Numerically, the average base flow was estimated as follows: $467 \mathrm{ft}^{3} / \mathrm{s}$ $185 \mathrm{ft}^{3} / \mathrm{s}-54 \mathrm{ft}^{3} / \mathrm{s}-45 \mathrm{ft}^{3} / \mathrm{s}-118 \mathrm{ft}^{3} / \mathrm{s}=65 \mathrm{ft}^{3} / \mathrm{s}$ (U.S. Geological Survey, 1990-91a).

Discharge by irrigation, rural-water-system, and municipal wells was obtained from annual irrigation data supplied by the South Dakota Department of Environment and Natural Resources, Water Rights Program (formerly known as the Water Rights Division); by the U.S. Geological Survey, Iowa District; and from pumpage records from rural-water systems and municipalities. The average pumping rate for irrigation, rural-water systems, and municipal wells for $1985-87$ was $2.23 \mathrm{ft}^{3} / \mathrm{s}$.

\section{DESCRIPTION OF THE DIGITAL MODEL}

A digital-computer model, or simply a digital model, is a mathematical model that uses a digital computer to compute approximate solutions to the partialdifferential equations that describe ground-water flow. The continuous derivatives of the partial-differential equations of ground-water flow are replaced by finitedifference approximations at the nodes (centroids) of cells arranged in a rectangular grid. The digital model selected for this study was the U.S. Geological Survey's modular three-dimensional finite-difference ground-water-flow model (MODFLOW), written by McDonald and Harbaugh (1988). 
Table 1. Pan evaporation for Sioux Falls, S. Dak., and estimated potential evapotranspiration, selected years

\begin{tabular}{|c|c|c|c|c|c|c|}
\hline Month & $\begin{array}{l}\text { Average pan } \\
\text { evaporation }{ }^{1} \\
\text { (inches) }\end{array}$ & $\begin{array}{c}\text { Estimated } \\
\text { potential } \\
\text { evapotrans- } \\
\text { piration }{ }^{2} \\
\text { (inches) }\end{array}$ & $\begin{array}{l}1985 \text { pan } \\
\text { evaporation } \\
\text { (inches) }\end{array}$ & $\begin{array}{l}1985 \text { estimated } \\
\text { evapotrans- } \\
\text { piration }{ }^{2} \\
\text { (inches) }\end{array}$ & $\begin{array}{c}1986 \text { pan } \\
\text { evaporation } \\
\text { (inches) }\end{array}$ & $\begin{array}{c}1986 \text { estimated } \\
\text { evapotrans- } \\
\text { piration }{ }^{2} \\
\text { (inches) }\end{array}$ \\
\hline April & 5.92 & 4.36 & ${ }^{3} 5.72$ & 4.22 & ${ }^{3} 5.36$ & 3.95 \\
\hline May & 8.35 & 6.15 & 9.00 & 6.63 & 7.31 & 5.39 \\
\hline June & 9.82 & 7.24 & 9.24 & 6.81 & 9.81 & 7.23 \\
\hline July & 10.31 & 7.60 & 9.93 & 7.32 & 10.73 & 7.91 \\
\hline August & 8.71 & 6.42 & 6.70 & 4.94 & 8.18 & 6.03 \\
\hline September & 6.66 & 4.91 & 3.78 & 2.79 & 4.81 & 3.54 \\
\hline October & 3.65 & 2.69 & ${ }^{4} 3.65$ & 2.69 & ${ }^{3} 2.71$ & 2.00 \\
\hline
\end{tabular}

${ }^{1}$ National Oceanic and Atmospheric Administration, 1976-94.

${ }^{2}$ The mean monthly pan evaporation multiplied by 0.737 (National Oceanic and Atmospheric Administration, 1982a, 1982b).

${ }^{3}$ Pan evaporation at Pickstown, S. Dak. (approximately 80 miles west of study area).

${ }^{4}$ Value estimated from other years.

The model was designed taking into consideration the geohydrologic setting, hydraulic properties including hydraulic conductivity and specific yield, aquifer recharge and discharge, and aquifer boundaries. These hydrologic aspects, some of which require simplifying assumptions, were represented by subdividing the simulated area into a series of finite-difference cells within which aquifer characteristics were assumed to be uniform. In this way, values are assigned for the aquifer characteristics that define the system at each model cell. Flow in the aquifer was assumed to be lateral and two dimensional. The resulting arrays that describe aquifer characteristics for specified periods of time were assembled to portray the aquifer in a form such that computerized numerical-solution techniques could be used. The series of finite-difference equations was solved using the Strongly Implicit Procedure (SIP) technique. This solution sequence was used to calibrate the model, test interpretations, and analyze hypothetical hydrologic situations.

\section{Representation of Physical Geometry}

The model grid of 208 rows and 80 columns (fig. 8) was superimposed over the Big Sioux aquifer. A buffer zone of inactive cells was included on the east and west sides of the aquifer to allow for possible future revisions in the boundaries of the aquifer. A large buffer also was included on the west side to allow for possible future inclusion of the adjacent aquifers in South Dakota that interact with the Big Sioux aquifer.
A large buffer zone was also built onto the right side of the model to allow inclusion of the Big Sioux aquifer and adjacent aquifers if, and when, detailed studies are done in Iowa to more accurately define the aerial extent of the aquifer system. Again, it should be emphasized that it was not an objective of the study to model the Big Sioux aquifer in Iowa. Rather, observation-well data on the Iowa side were used to ensure that the model was adequately reflecting ground-water/surfacewater interactions between the Big Sioux aquifer and the Big Sioux River, thereby providing more confidence in the results obtained for Lincoln and Union Counties.

Each cell is one-quarter mile square and represents $0.0625 \mathrm{mi}^{2}$, except for columns 1 through 6 , which are of variable width. The location of cells representing no-flow boundaries, general-head boundaries, and constant-head boundaries is shown in figure 8 . The model grid, as described, contains 16,640 cells, with 1,715 active cells representing the Big Sioux aquifer. A bottom-of-aquifer altitude for each model cell was based on test-hole and drillers' logs completed within the aquifer.

Leakage from the surrounding till generally is assumed to be negligible. Therefore, no-flow boundaries were used to represent areas where the aquifer is bordered by till. Leakage from the Shindler, Newton Hills, and Brule Creek aquifers, as well as small alluvial valleys draining to the Big Sioux River, are simulated with general-head boundary cells. The Brule Creek aquifer is not directly connected with the Big 


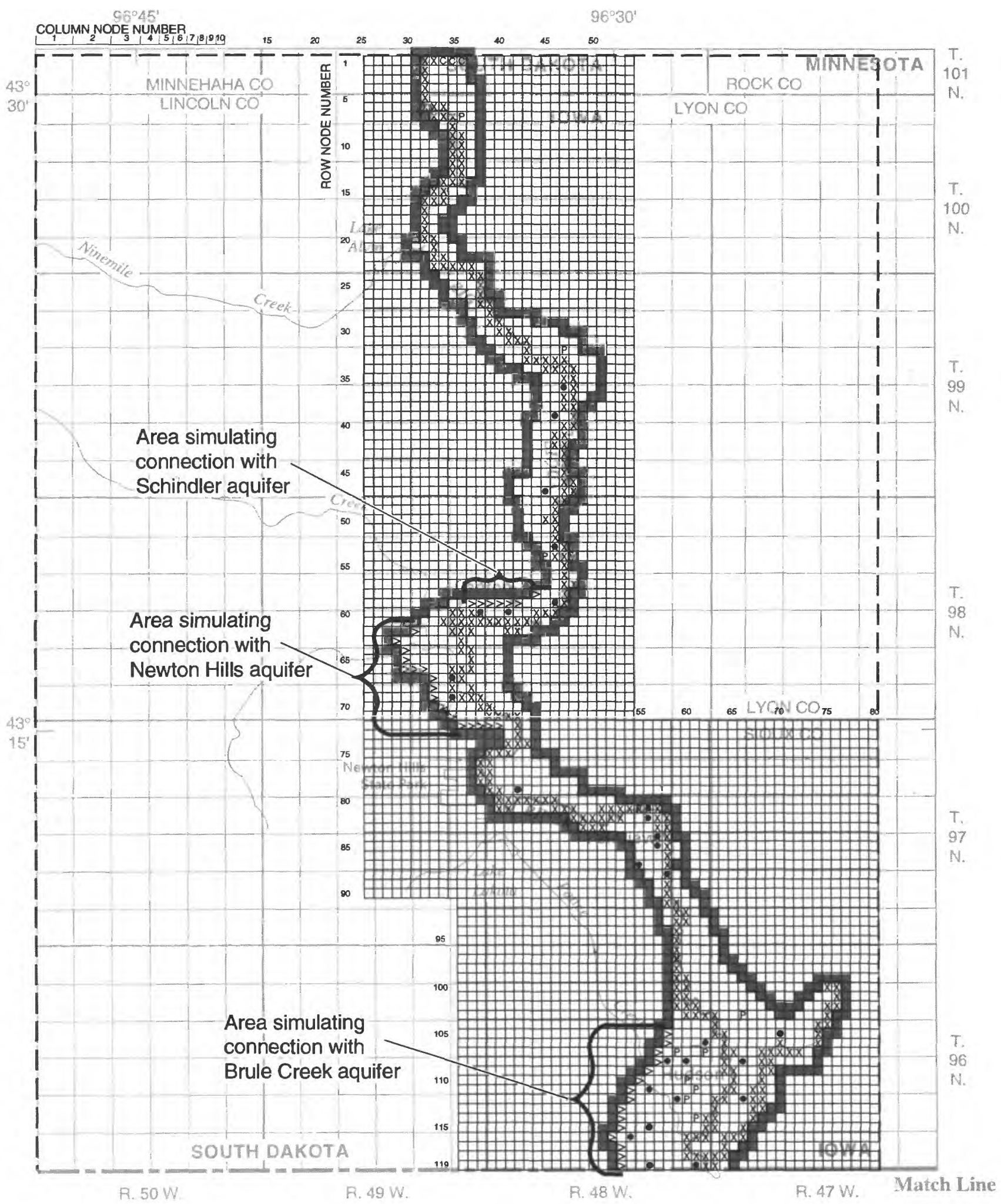

Figure 8. Model area and boundary conditions represented in the model and location of observation and pumping wells used for steady-state simulation. 


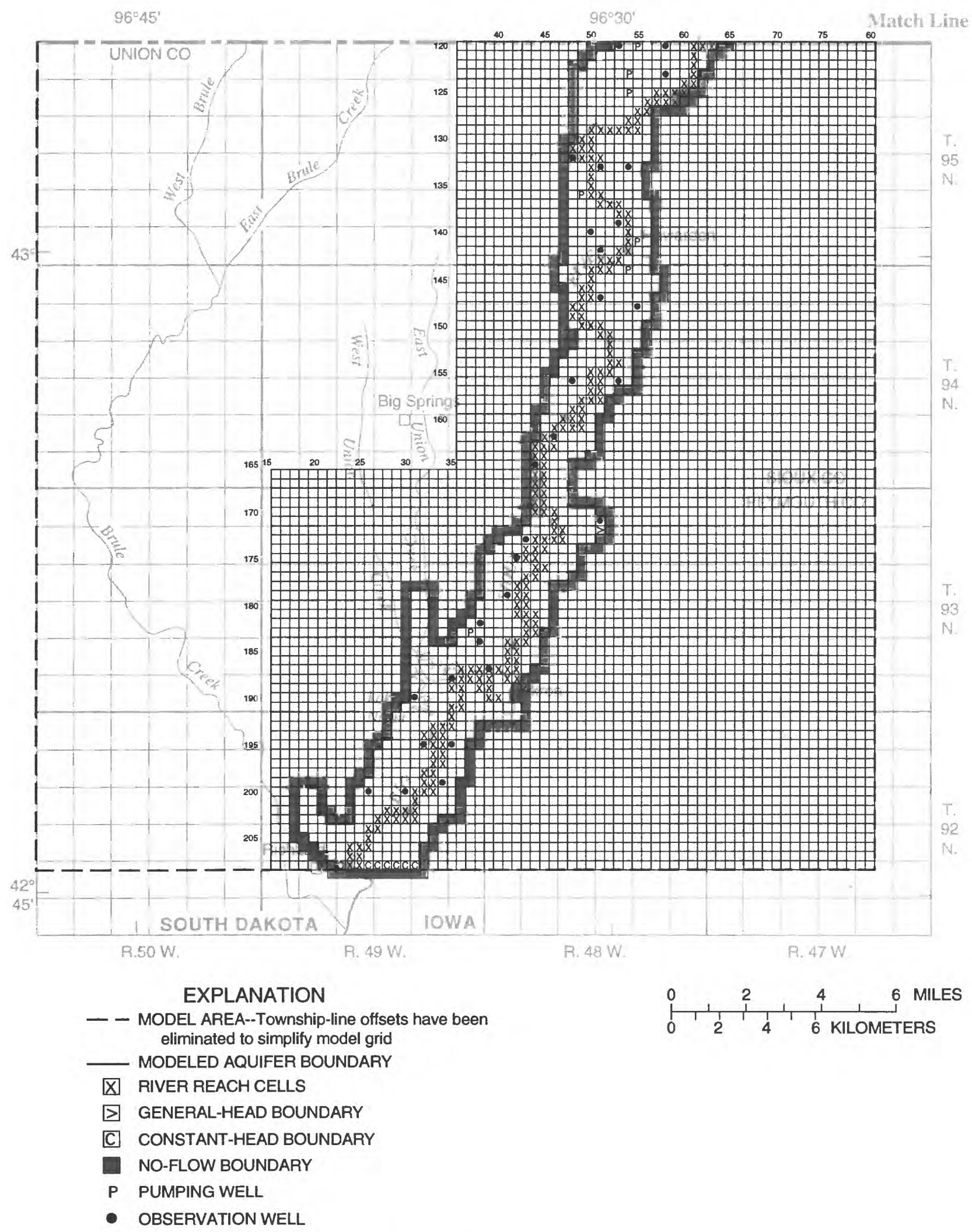

Figure 8. Model area and boundary conditions represented in the model and location of observation and pumping wells used for steady-state simulation.--Continued 
Sioux aquifer. However, an analysis of observationwell water levels indicates some ground-water influx through the sandy till (Niehus, 1994). An estimated inflow was calculated using Darcy's law. Data collected from observation wells in these aquifers were used to establish the hydraulic heads. The calculated flow and measured heads were used in assigning the model input for the general-head boundary areas. Connections with the Big Sioux aquifer north of the model area (Sioux Falls Management Unit) and with the Missouri aquifer south of the model area are simulated by constant-head boundaries.

\section{Representation of Hydraulic Properties}

The assignment of an average aquifer hydraulic conductivity, and specific yield for each model cell is necessitated by the simplifying assumptions that aquifer materials are uniform in each cell, and that the test-hole and drillers' logs adequately describe the aquifer materials in each cell. Because no aquifer tests have been completed in the study area, the hydraulic conductivity was estimated by comparing grain size reported in drillers' logs with similar grain sizes in other areas of the Big Sioux aquifer where aquifer tests have been completed (Koch, 1980). In portions of the study area where no grain-size data were available, the hydraulic conductivity was estimated from the hydraulic conductivities determined for surrounding areas. Estimated hydraulic conductivity for the model ranged from 200 to $400 \mathrm{ft} / \mathrm{d}$ depending on grain size, with most areas being assigned $250 \mathrm{ft} / \mathrm{d}$.

A uniform specific yield value of 0.20 was selected for use in this study based on Koch (1982), Hansen (1988), and Ohland (1990). This value is also close to the upper end of the range of specific yields used for the Big Sioux aquifer in Codington and Grant Counties (Putnam and Thompson, 1996).

\section{Representation of Recharge and Discharge}

A spatially uniform constant areal recharge rate was assigned to each active model cell. The recharge rate calculated from observation well rises ranged from 12.96 to $2.14 \mathrm{in} / \mathrm{yr}$ and averaged $7.54 \mathrm{in} / \mathrm{yr}$. A uniform steady-state recharge rate of $6.33 \mathrm{in} / \mathrm{yr}$ best reproduced average water levels (1976-94). The temporal distribution of recharge was quantified by matching simulated water-level hydrographs with measured water levels in observation wells. This process is further described in the subsequent model calibration section. An iteratively derived monthly recharge multiplication factor was used to convert precipitation values to areal recharge values. Thus, the monthly recharge multiplication factor is the fraction of precipitation that penetrates through the soil and is not lost to soil evapotranspiration. A summary of the monthly recharge factors and recharge rates used in the model is shown in table 2.

The evapotranspiration module of MODFLOW is based on the assumption that ground-water evapotranspiration decreases linearly from a maximum at land surface, to zero at an assigned extinction depth. An average land-surface elevation was required for each cell in the model. Land-surface elevation was determined from U.S. Geological Survey 7.5-minute quadrangle maps and ranged from $1,085 \mathrm{ft}$ above sea level in the extreme southeastern tip of Union County to $1,565 \mathrm{ft}$ in southeastern Lincoln County (Niehus, 1994). Following Koch (1982), an extinction depth of $5 \mathrm{ft}$ was used. Evapotranspiration is simulated in this model only during spring, summer, and fall months when the ground is not frozen.

Recharge to the aquifer from the Big Sioux River and its tributaries and discharge from the aquifer to the river and its tributaries were simulated using the river module within MODFLOW. The river was discretized into reaches, which are areas where the river flows through model cells as shown in figure 8 . Flow between the river and the aquifer is calculated in the model by applying Darcy's law as follows:

$$
Q R I V=\left(K^{*} \mathrm{~L}^{*} \mathrm{~W}\right) / M^{*}(H R I V-H A Q)
$$

where

$$
\begin{aligned}
Q R I V= & \text { the flow between the river and the aquifer; } \\
K= & \text { hydraulic conductivity of the riverbed } \\
& \text { material; } \\
L= & \text { length of the river; } \\
W= & \text { width of the river; } \\
M= & \text { thickness of the riverbed material; } \\
H R I V= & \text { head (stage) of the river; and } \\
H A Q= & \text { head of the aquifer in the cell underlying the } \\
& \text { river reach. }
\end{aligned}
$$

The average stage of the Big Sioux River and its tributaries for the steady-state simulation of 1976-94 was estimated using data from streamflow-gaging 
Table 2. Average monthly precipitation and estimated recharge

\begin{tabular}{|c|c|c|c|c|c|c|c|}
\hline \multirow[b]{2}{*}{ Month } & \multirow[b]{2}{*}{$\begin{array}{c}\text { Recharge } \\
\text { multiplication } \\
\text { factor }^{1}\end{array}$} & \multicolumn{2}{|c|}{ Normal (1976-94) } & \multicolumn{2}{|c|}{1985} & \multicolumn{2}{|c|}{1986} \\
\hline & & $\begin{array}{c}\text { Average } \\
\text { precipitation } \\
\text { (inches) }\end{array}$ & $\begin{array}{c}\text { Recharge to } \\
\text { the aquifer } \\
\text { (inches) }\end{array}$ & $\begin{array}{c}\text { Average } \\
\text { precipitation }{ }^{2} \\
\text { (inches) }\end{array}$ & $\begin{array}{l}\text { Recharge to } \\
\text { the aquifer } \\
\text { (inches) }\end{array}$ & $\begin{array}{c}\text { Average } \\
\text { precipitation }{ }^{2} \\
\text { (inches) }\end{array}$ & $\begin{array}{c}\text { Recharge to } \\
\text { the aquifer } \\
\text { (inches) }\end{array}$ \\
\hline February & 0.20 & 0.48 & 0.10 & 0.04 & 0.01 & 0.01 & 0.00 \\
\hline March & 0.35 & 1.65 & 0.58 & 1.84 & 0.64 & 1.90 & 0.67 \\
\hline June & 0.25 & 3.83 & 0.96 & 3.70 & 0.92 & 3.61 & 0.90 \\
\hline July & 0.23 & 3.58 & 0.82 & 0.71 & 0.16 & 2.22 & 0.51 \\
\hline August & 0.08 & 3.27 & 0.26 & 5.41 & 0.43 & 2.51 & 0.20 \\
\hline September & 0.08 & 2.42 & 0.19 & 4.01 & 0.32 & 5.70 & 0.46 \\
\hline Annual & & 25.18 & 6.33 & 28.45 & 7.45 & 27.98 & 7.23 \\
\hline
\end{tabular}

${ }^{1}$ The fraction of average precipitation that could potentially recharge the aquifer.

${ }^{2}$ Average of Centerville and Canton, S. Dak. (National Oceanic and Atmospheric Administration, 1976-94).

${ }^{3} \mathrm{Calculated}$ by multiplying the monthly precipitation by the recharge multiplication factor.

stations (U.S. Geological Survey, 1977-95a, b) located on the Big Sioux River at North Cliff Avenue at Sioux Falls and at Akron, Iowa; Beaver Creek at Canton; Rock River near Rock Valley, Iowa, and measurements from various bridges throughout the study area (fig. 3). The stage of each reach for each monthly transient simulation was interpolated from the mean monthly measured stages at the stations and bridges mentioned above. River stage was held constant for each individual month, and for the steady-state simulation. The river-bottom altitude was interpolated in much the same way as river stages.

The hydraulic conductivity of the riverbed was held constant through time and was estimated to be $0.5 \mathrm{ft} / \mathrm{d}$ in most areas. This value is within the range of 0.5 to $1.0 \mathrm{ft} / \mathrm{d}$ determined by Jorgensen and Ackroyd (1973). In the vicinity of Canton where the river has cut through the aquifer and flows over the till underlying the aquifer, the river reaches were assigned a reduced riverbed conductance to reflect the different riverbed material. Riverbed conductance, which is calculated using the hydraulic conductivity and the lateral area covered by the river length and width within a cell, varies in each cell. The average width and length of the river in each model cell was determined from U.S. Geological Survey 7.5-minute topographic maps; the width averaged $110 \mathrm{ft}$. The thickness of the riverbed material was assumed to be $1 \mathrm{ft}$.

Withdrawals from pumping wells within the study area are simulated using the well module of MODFLOW. Pumping rates from irrigation wells in South Dakota were obtained from water-use records collected by the South Dakota Department of Environment and Natural Resources, Water Rights Program. Irrigation pumping rates in Iowa were obtained from the Iowa State Water Use Database. Pumping records for the cities of Fairview, Hudson, and Hawarden, and for the rural-water systems of Rock Valley, Lincoln, and Lyon-Sioux were obtained from the appropriate official at each city or system.

\section{CALIBRATION OF THE DIGITAL MODEL}

Once the model is constructed, it must be calibrated to ensure that the assigned aquifer characteristics are representative of those in the actual system and that it will simulate observed conditions as accurately as possible. Calibration was accomplished by adjusting the model data input within acceptable ranges until the model adequately simulated observed heads and ground-water discharge to rivers. Model calibration involved a steady-state simulation, a steady-state sensitivity analysis, and a transient simulation. 
The steady-state conditions (1976-94) were simulated by setting the change in storage to zero and using average recharge, evapotranspiration, and pumpage. The simulated water levels were compared with the average of water levels measured at observation wells for 1976-94. The steady-state simulated ground-water discharge to rivers also was compared with estimated ground-water discharge to the rivers. Monthly transient simulations (1985 and 1986) and the antecedent simulations leading up to them included storage and time-dependent recharge, evapotranspiration, and pumpage. Parameters that were varied included hydraulic conductivity, recharge, evapotranspiration extinction depth, and specific yield. Recharge to the aquifer was varied by adjusting the monthly recharge multiplication factors during transient simulations to better approximate water-level hydrographs. Following each change in recharge factors, the steady-state and antecedent simulations were run again to provide appropriately adjusted antecedent conditions for the transient simulation. The model was considered calibrated when the model parameters produced the best composite set of average arithmetic and absolute differences between simulated and observed water levels for the steady-state simulation and the 1985 and 1986 monthly transient simulations (table 3 ), and simulated base flows approached estimated base flow values.

Table 3. Comparison between simulated and measured water levels in the aquifer for steady-state and transient simulations $[--$, no data $]$

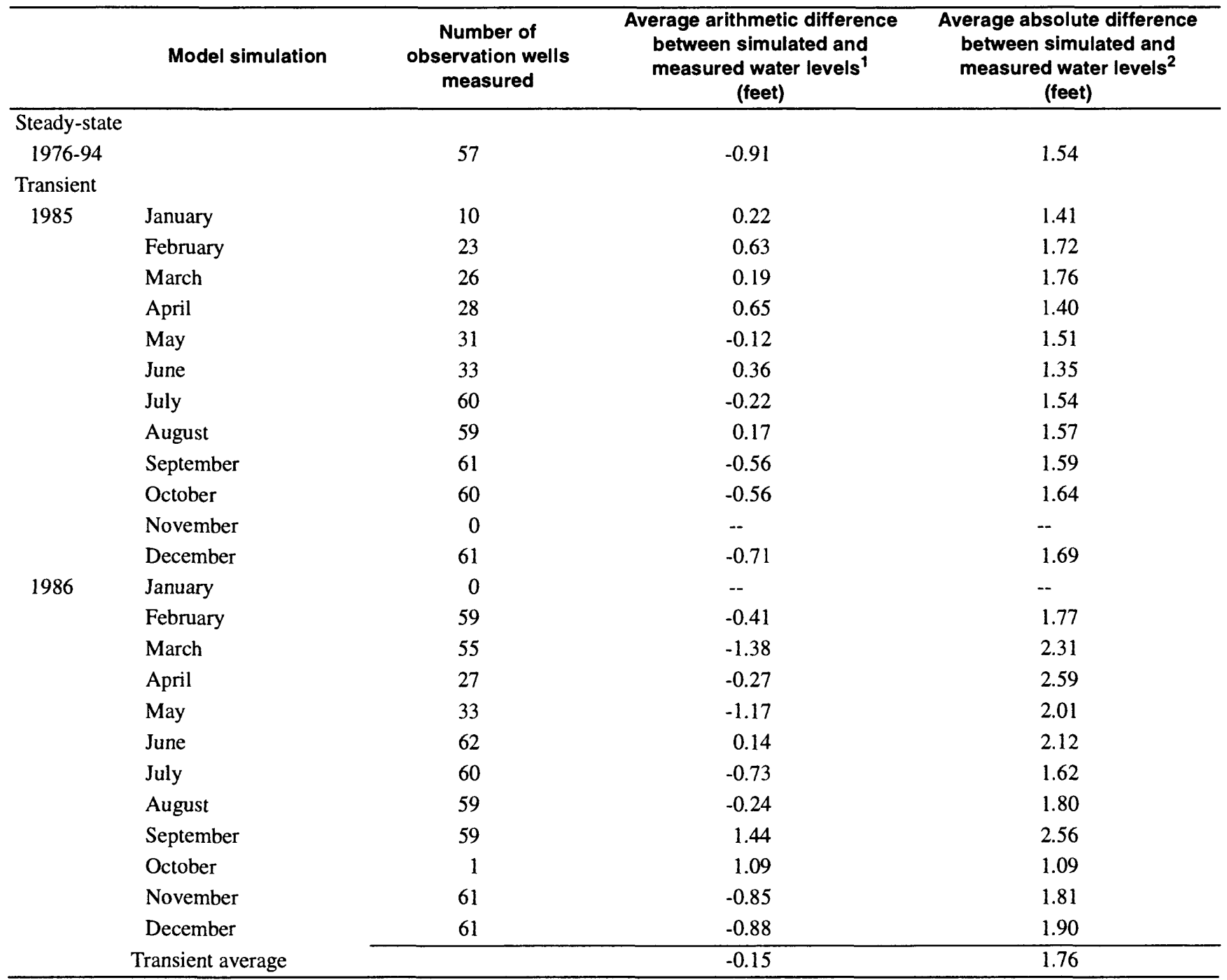

${ }^{1}$ Summation of the differences between simulated and measured water levels divided by the number of observation wells measured. Positive number indicates simulated water level higher than measured water level; negative number indicates simulated water level lower than the measured water level.

${ }^{2}$ Summation of the absolute values of simulated minus measured water levels, divided by the number of observation wells measured. 
Water-level measurements were recorded regularly at 57 observation wells during the steady-state period of 1976-94. An additional set of observation wells was measured during 1985 and 1986. During that period, field conditions dictated that not all of the 62 observation wells could be reached each month, and no wells were measured in November 1985 and January 1986.

To take into account antecedent conditions, heads from the steady-state simulation were used as initial conditions for an annual simulation of 1983 . The resulting heads were then used as initial conditions for a 60-day simulation of January and February 1984. This set of heads was then used to start a series of 90-day spring, summer, and fall simulations, followed by a monthly simulation of December 1984 . The monthly simulations of 1985 and 1986 followed, using the simulated December 1984 heads as initial conditions.

\section{Steady-State Simulation}

Steady-state conditions were assumed to be represented by the average hydrologic conditions (water levels, evapotranspiration, precipitation, streamflow, and pumpage) for 1976 to 1994 . This period was chosen because climatic conditions were near the longterm normal and substantial records were available for use as model input data. River stages, streamflows, evaporation, and precipitation data were available for the entire period. Observation-well water-level records were available for several wells for most of this period; however, water-level data were available for many more wells beginning in 1984. The data from all of these wells were used in the steady-state calibration, although the average water levels for the wells likely would be slightly different if data for the entire period had been available. Longer periods (for example, 1961-90) had limited observation-well and river-stage data available, and the simulations would have involved more extensive interpolations and assumptions.

The model parameters were varied within acceptable ranges until ground-water levels and ground-water discharges to rivers adequately approximated measured data. Adequacy of the steady-state model was evaluated by comparing the average arithmetic and average absolute difference between the simulated and measured water levels for the 57 observation wells used in steady-state calibration. The average absolute difference was calculated as the average of the absolute values of the differences between the simulated and measured water levels at each well. The average arithmetic difference was $-0.91 \mathrm{ft}$, and the average absolute difference was $1.54 \mathrm{ft}$. These differences were considered acceptable because many of the wells had data for only a portion of the steady-state period. In addition, all of the observation wells were measured more often during the summer, when field conditions permitted, and less often during the winter, when snow cover and cold temperatures hindered data collection. Consequently, the average measured water levels are skewed towards the higher ground-water levels of spring and summer, accounting for some of the difference between simulated and measured water levels. Grid size also may influence the difference between simulated and measured water levels. The 1,320-ft grid size used in the model was chosen for compatibility with other models in the Big Sioux Hydrology Study (Koch, 1980, 1982; Hansen, 1988; Putnam and Thompson, 1996). However, such a grid size also means that there could be as much as $933 \mathrm{ft}$ between the location of an observation well and the model node. The simulated water level for a cell represents the average value for that cell, whereas the water level for an observation well is a measured value at a specific point in the cell. The pumping of a well near an observation well may influence measured water levels by causing a drawdown that makes the observed water level too low to adequately represent the overall cell. Differences between simulated steady-state and measured water levels are shown in table 4.

The simulated hydrologic budget for the steadystate model is shown in table 5. Ground-water inflow from the adjacent aquifers accounts for about 26 percent of the total inflow into the system. Discharge to rivers is approximately 78 percent of the total outflow from the system. The net ground-water discharge (outflow-inflow) to the Big Sioux River and its tributaries within the aquifer extent was simulated to be $53 \mathrm{ft}^{3} / \mathrm{s}$, which compares reasonably with $65 \mathrm{ft}^{3} / \mathrm{s}$, the estimated ground-water discharge to the Big Sioux River during 1990 (a year with near-normal precipitation). This difference could be due to the fact that the model is simulating steady-state, or average water levels, while the calculated base flow is from a single year. The estimated base flow also includes the small contributions from intermittent streams that were too small to be included in the model. 
Table 4. Difference between simulated and measured water levels for steady-state simulation

\begin{tabular}{|c|c|c|c|c|c|}
\hline \multicolumn{2}{|c|}{ Location of nearest node } & \multirow[b]{2}{*}{ Well location } & \multirow{2}{*}{$\begin{array}{c}\text { Measured } \\
\text { water level } \\
\text { (feet above } \\
\text { sea level) }\end{array}$} & \multirow{2}{*}{$\begin{array}{c}\text { Simulated } \\
\text { water level } \\
\text { (feet above } \\
\text { sea level) }\end{array}$} & \multirow[b]{2}{*}{ Difference } \\
\hline Row & Column & & & & \\
\hline 36 & 47 & 99N48W21BBAA & $1,245.92$ & $1,246.56$ & 0.64 \\
\hline 39 & 46 & 99N48W20DDDD & $1,244.01$ & $1,245.04$ & 1.03 \\
\hline 47 & 45 & 99N48W32DCDD & $1,241.76$ & $1,240.89$ & -0.87 \\
\hline 53 & 46 & 98N48W8ADDA & $1,235.01$ & $1,236.82$ & 1.81 \\
\hline 59 & 46 & 98N48W17DDCB2 & $1,235.04$ & $1,233.72$ & -1.32 \\
\hline 60 & 38 & 98N49W24AAAA & $1,236.27$ & $1,237.05$ & 0.78 \\
\hline 60 & 41 & $98 \mathrm{~N} 48 \mathrm{~W} 19 \mathrm{ABBB}$ & $1,239.77$ & $1,240.05$ & 0.28 \\
\hline 67 & 35 & 98N49W25CCBC & $1,226.39$ & $1,227.70$ & 1.31 \\
\hline 69 & 35 & 98N49W36BCBC & $1,228.01$ & $1,230.85$ & 2.84 \\
\hline 79 & 42 & 97N48W7DDDD IO & $1,205.92$ & $1,206.66$ & 0.74 \\
\hline 81 & 56 & 97N48W14BDCC & $1,195.60$ & $1,195.56$ & -0.04 \\
\hline 82 & 56 & 97N48W14CACA2 & $1,197.47$ & $1,195.90$ & -1.57 \\
\hline 84 & 57 & 97N48W23ABCA & $1,193.38$ & $1,194.22$ & 0.84 \\
\hline 85 & 57 & 97N48W23ACDB & $1,198.59$ & $1,194.92$ & -3.67 \\
\hline 87 & 55 & 97N48W23CCDD & $1,201.07$ & $1,196.45$ & -4.62 \\
\hline 88 & 58 & 97N48W26AABB & $1,192.65$ & $1,192.36$ & -0.29 \\
\hline 105 & 70 & 96 N47W 16BCCB IO & $1,197.63$ & $1,193.51$ & -4.12 \\
\hline 106 & 62 & 96N48W13DAAD & $1,187.35$ & $1,188.79$ & 1.44 \\
\hline 108 & 58 & 96N48W23AAAA & $1,204.92$ & $1,204.03$ & -0.89 \\
\hline 108 & 60 & 96N48W24BAAA & $1,202.64$ & $1,196.72$ & -5.92 \\
\hline 108 & 66 & 96 N47W20BBCB IO & $1,192.05$ & $1,185.47$ & -6.58 \\
\hline 111 & 56 & 96N48W23CDDD & $1,201.36$ & $1,201.97$ & 0.61 \\
\hline 112 & 59 & 96N48W25BBAA & $1,195.76$ & $1,191.56$ & -4.20 \\
\hline 112 & 66 & 96N47W30AAAA IO & $1,182.96$ & $1,182.01$ & -0.95 \\
\hline 115 & 56 & 96N48W26CDDD & $1,195.87$ & $1,194.43$ & -1.44 \\
\hline 116 & 54 & 96N48W34AAAA & $1,196.63$ & $1,198.22$ & 1.59 \\
\hline 119 & 56 & 96N48W35CDDD & $1,193.46$ & $1,191.17$ & -2.29 \\
\hline 119 & 61 & 96N48W36DCCD & $1,175.59$ & $1,174.17$ & -1.42 \\
\hline 120 & 53 & 95N48W3ABAA & $1,197.19$ & $1,197.08$ & -0.11 \\
\hline 120 & 58 & 95N48W2AAAA & $1,187.72$ & $1,184.54$ & -3.18 \\
\hline 123 & 58 & 95N48W2DDDD & $1,184.66$ & $1,180.00$ & -4.66 \\
\hline 132 & 48 & $95 N 48 W 21 B A C A$ & $1,162.31$ & $1,162.54$ & 0.23 \\
\hline 133 & 51 & $95 \mathrm{~N} 48 \mathrm{~W} 22 \mathrm{BCCC} \mathrm{IO}$ & $1,164.02$ & $1,163.49$ & -0.53 \\
\hline 133 & 54 & 95N48W22ADDD IO & $1,170.77$ & $1,169.36$ & -1.41 \\
\hline 139 & 53 & 95N48W27DCCC & $1,161.12$ & $1,159.44$ & -1.68 \\
\hline 140 & 50 & 95N48W33AAAA & $1,164.02$ & $1,162.94$ & -1.08 \\
\hline 142 & 51 & 95N48W34CBCC & $1,159.91$ & $1,160.36$ & 0.45 \\
\hline 147 & 51 & $94 N 48 W 3 C C D C$ IO & $1,159.24$ & $1,158.44$ & -0.80 \\
\hline 148 & 55 & 94N48W11BBBB IO & $1,164.29$ & $1,162.30$ & -1.99 \\
\hline 156 & 48 & 94N48W21BAAA & $1,154.05$ & $1,153.19$ & -0.86 \\
\hline 156 & 53 & $94 \mathrm{~N} 48 \mathrm{~W} 22 \mathrm{ABAA}$ IO & $1,158.66$ & $1,156.30$ & -2.36 \\
\hline 162 & 46 & 94N48W29DABB & $1,145.52$ & $1,146.52$ & 1.00 \\
\hline 165 & 44 & 94N48W32BDBA & $1,142.30$ & $1,143.18$ & 0.88 \\
\hline 171 & 51 & 93N48W3CCC IO & $1,150.78$ & $1,149.59$ & -1.19 \\
\hline 173 & 43 & 93N48W8BCDC & $1,139.44$ & $1,139.96$ & 0.52 \\
\hline
\end{tabular}


Table 4. Difference between simulated and measured water levels for steady-state simulation—Continued

\begin{tabular}{|c|c|c|c|c|c|}
\hline \multicolumn{2}{|c|}{ Location of nearest node } & \multirow[b]{2}{*}{ Well location } & \multirow{2}{*}{$\begin{array}{c}\text { Measured } \\
\text { water level } \\
\text { (feet above } \\
\text { sea level) }\end{array}$} & \multirow{2}{*}{$\begin{array}{c}\text { Simulated } \\
\text { water level } \\
\text { (feet above } \\
\text { sea level) }\end{array}$} & \multirow[b]{2}{*}{ Difference } \\
\hline Row & Column & & & & \\
\hline 175 & 42 & 93N48W7DCDA & $1,141.05$ & $1,138.96$ & -2.09 \\
\hline 179 & 41 & 93N48W18DCCD & $1,138.26$ & $1,137.45$ & -0.81 \\
\hline 182 & 38 & 93N49W24DAAA & $1,132.63$ & $1,133.26$ & 0.63 \\
\hline 184 & 38 & 93N49W25AAAA & $1,133.14$ & $1,131.44$ & -1.70 \\
\hline 187 & -39 & 93N48W30CCAC & $1,130.95$ & $1,129.84$ & -1.11 \\
\hline 188 & 35 & 93N49W36BBBB & $1,126.72$ & $1,126.57$ & -0.15 \\
\hline 190 & 31 & 93N49W35CBCB & $1,127.93$ & $1,126.97$ & -0.96 \\
\hline 195 & 32 & $92 \mathrm{~N} 49 \mathrm{~W} 2 \mathrm{CDDD}$ & $1,122.13$ & $1,122.15$ & 0.02 \\
\hline 195 & 35 & $92 \mathrm{~N} 49 \mathrm{~W} 1 \mathrm{CCCC} \mathrm{IO}$ & $1,122.24$ & $1,122.81$ & 0.57 \\
\hline 199 & 34 & 92N49W11DDDD & $1,121.41$ & $1,120.95$ & -0.46 \\
\hline 200 & 26 & 92N49W16AAAA & $1,120.12$ & $1,118.33$ & -1.79 \\
\hline 200 & 30 & 92N49W15AAAA & $1,119.87$ & $1,119.16$ & -0.71 \\
\hline \multicolumn{5}{|c|}{ Average arithmetic difference ${ }^{1}$} & -0.91 \\
\hline \multicolumn{5}{|c|}{ Average absolute difference ${ }^{2}$} & 1.54 \\
\hline
\end{tabular}

${ }^{1}$ The sum of the differences between simulated and measured water levels divided by the number of observation wells measured.

${ }^{2}$ The sum of the absolute values of the differences between simulated and observed water levels divided by the number of observation wells measured.

The model was considered calibrated when simulated water levels in the Big Sioux aquifer adequately matched water levels in 57 observation wells (fig. 9), and when simulated ground-water discharge to the rivers approximated the estimated base flow of the Big Sioux River and tributaries. The aquifer hydraulic con- ductivity after calibration was $250 \mathrm{ft} / \mathrm{d}$ for most cells, and the riverbed conductance was $0.5 \mathrm{ft} /$ day except for the previously discussed area near Canton where the river has cut through the aquifer material. The steadystate recharge rate after calibration was $6.33 \mathrm{in} / \mathrm{yr}$, and the evapotranspiration extinction depth was $5 \mathrm{ft}$.

Table 5. Simulated aquifer water budget for steady-state conditions

\begin{tabular}{lcc}
\hline \multicolumn{1}{c}{ Budget component } & $\begin{array}{c}\text { Flow rates } \\
\text { (cubic feet } \\
\text { per second) }\end{array}$ & Percent \\
\hline INFLOWS & & \\
Recharge from precipitation & 49.58 & 64.91 \\
Recharge from rivers to the aquifer & 5.99 & 7.84 \\
Recharge from constant-head boundaries & 1.03 & 1.35 \\
Recharge from adjacent lateral aquifers & 19.78 & 25.90 \\
Total Inflows ${ }^{1}$ & 76.38 & 100.0 \\
& & \\
OUTFLOWS & & 16.78 \\
Evapotranspiration from the aquifer & 12.82 & 2.36 \\
Pumpage & 1.80 & 77.72 \\
Discharge from the aquifer to rivers & 59.37 & 0.55 \\
Discharge to constant-head boundaries & 0.42 & 2.59 \\
Discharge to adjacent lateral aquifers & 1.98 & 100.0 \\
Total Outflows ${ }^{1}$ & 76.39 & \\
\hline
\end{tabular}

\footnotetext{
${ }^{1}$ Percent discrepancy is -0.01 .
} 


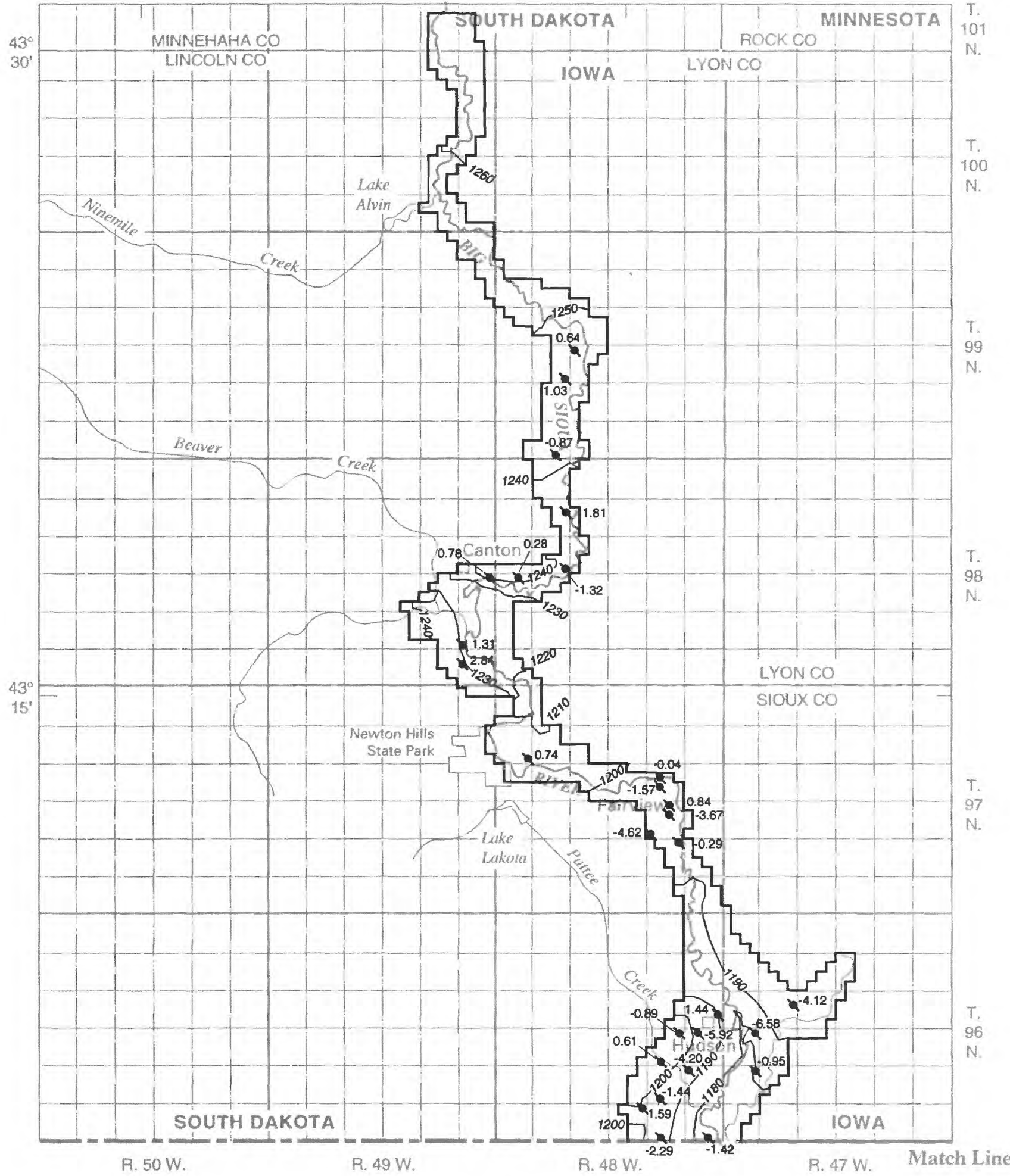

Figure 9. Simulated water-table configuration and difference between simulated and measured water levels, steady-state conditions. 


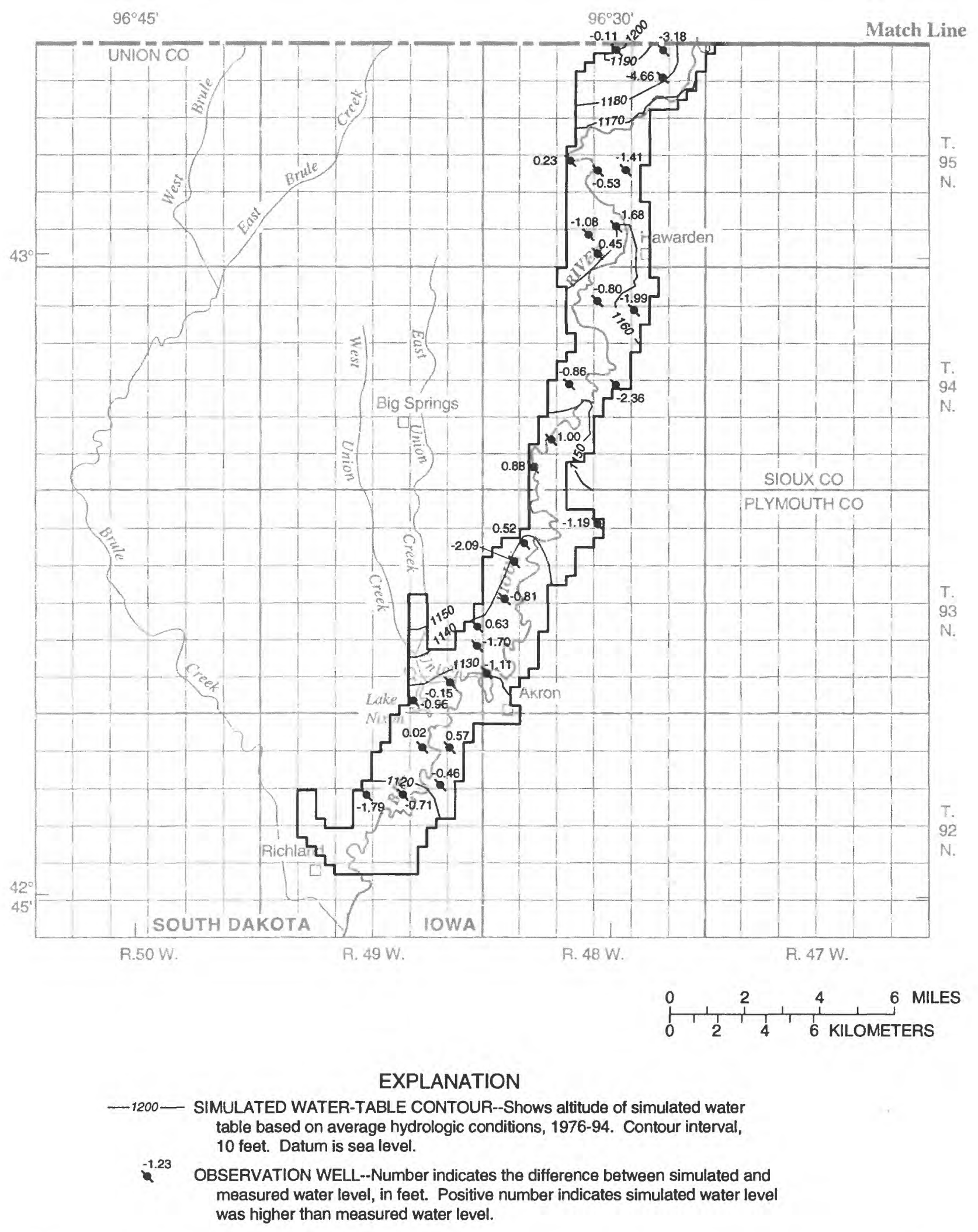

Figure 9. Simulated water-table configuration and difference between simulated and measured water levels, steady-state conditions.--Continued 


\section{Steady-State Sensitivity Analysis}

The model was tested under steady-state conditions to show the sensitivity of simulated ground-water levels to variations in recharge, riverbed conductance, aquifer hydraulic conductivity, evapotranspiration extinction depth, and maximum evapotranspiration rate. The sensitivity of the model to a particular stress factor is indicated by the relative changes in the simulated water levels which occur with a change in that stress factor. The results of these simulations are summarized in table 6 . Changes to the recharge rate had the greatest effect on simulated water levels. Changes to aquifer hydraulic conductivity appeared to have the second largest effect on the water levels. The remaining three stress factors--riverbed conductance, maximum evapotranspiration rate, and extinction depth--had smaller effects. Increasing or decreasing any of these three factors by 20 percent resulted in less than $0.1 \mathrm{ft}$ of change in the arithmetic difference, compared to the arithmetic difference of the calibrated model. The steady-state sensitivity analysis showed some evidence that increasing the recharge rate or decreasing the hydraulic conductivity would improve the agreement of simulated and observed water levels. While these adjustments would improve the steadystate agreement, they would not improve the transientsimulation agreement. The chosen solution provided the best compromise of closeness of simulated and measured water levels in both the steady-state and transient-state calibrations.

To demonstrate the relative importance of the general-head boundary cells used to simulate flow from adjacent aquifers to the Big Sioux aquifer, the model was run without the general-head boundary cells. The simulated heads decreased $2.58 \mathrm{ft}$, and the average absolute difference between the simulated and measured water levels increased $2.25 \mathrm{ft}$ from the calibrated steady-state model. This difference in fit was mainly concentrated near the areas where the general-head boundary cells are located. Water levels in other areas of the aquifer decreased much less.

Table 6. Model sensitivity to changes in aquifer hydraulic conductivity, riverbed hydraulic conductivity, maximum evapotranspiration rate, evapotranspiration extinction depth, and recharge rate

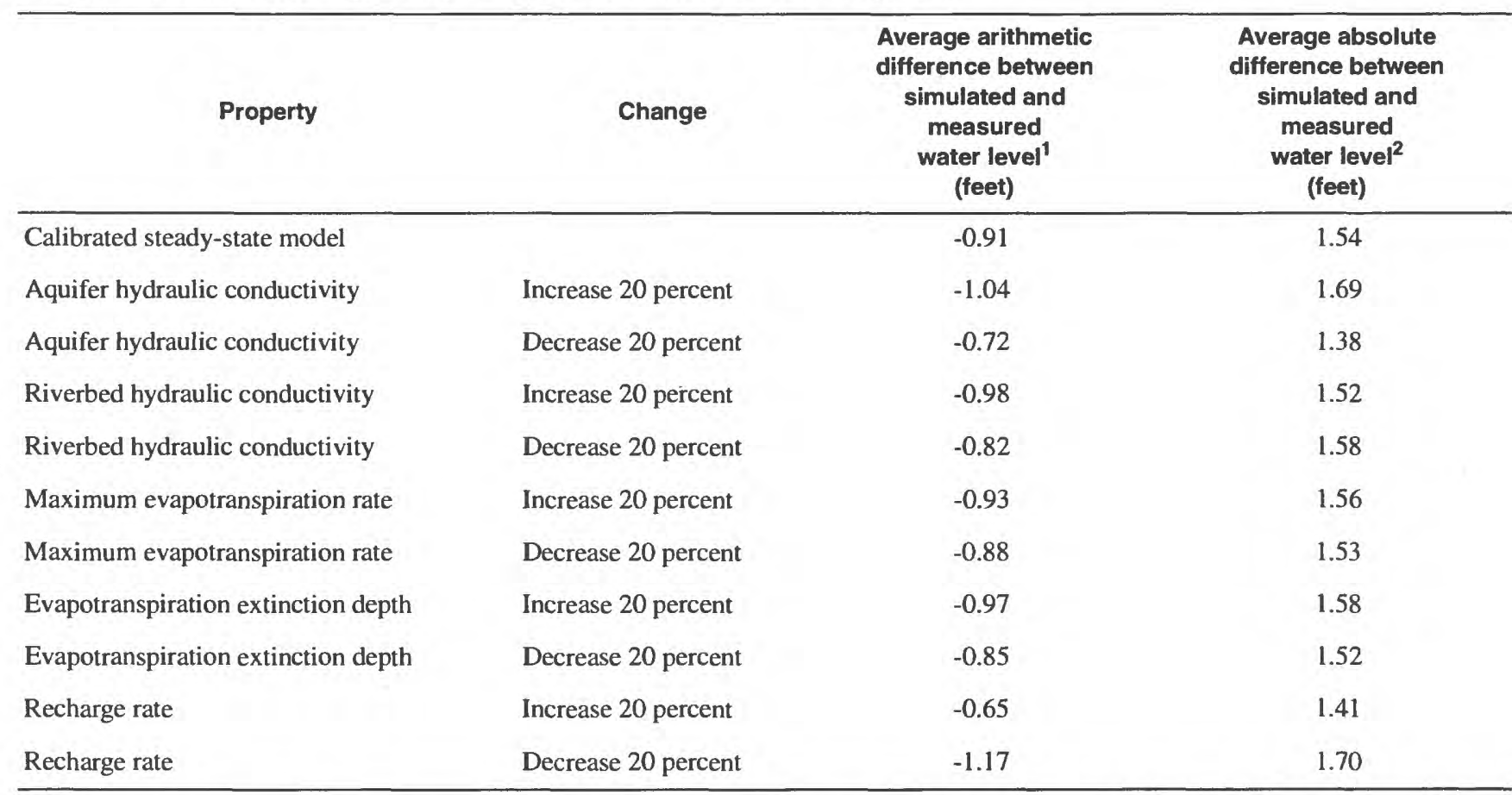

${ }^{\mathrm{I}}$ Summation of simulated minus measured water levels in corresponding model cells divided by number of observation wells with measured water levels. Positive number indicates simulated water level higher than the observed water level; negative number indicates simulated water level lower than the measured water level.

${ }^{2}$ Summation of the absolute values of simulated minus measured water levels in corresponding model cells divided by number of observation wells with measured water levels. 


\section{Transient Simulation}

Transient simulation differs from steady-state simulation in that storage change is included in the hydrologic budget. The years 1985 and 1986 were selected for simulation because extensive data were available for calibration, including observation-well water levels, river stages, and water-use information. Monthly simulations were conducted for this 2-year period, although no observation-well water-level data were available for November 1985 or January 1986.

The monthly maximum evapotranspiration rates used for the transient simulations were based on monthly pan evaporation data (pan evaporation multiplied by 0.737 , table 1 ). The river stages were estimated from data collected at streamflow-gaging stations located at Sioux Falls; Akron, Iowa; and Canton. Measurements at bridges were used to determine river stages between streamflow-gaging stations (fig. 3).

The average monthly arithmetic difference between simulated and measured water levels for the transient simulation period ranged from $-1.38 \mathrm{ft}$ in March 1986 to $1.44 \mathrm{ft}$ in September 1986 and averaged $-0.15 \mathrm{ft}$ (table 3 ). Ten of the 22 months for which data were available had an arithmetic difference between +0.5 and $-0.5 \mathrm{ft}$. The average absolute difference between simulated and measured water levels ranged from $1.09 \mathrm{ft}$ in October 1986 to $2.59 \mathrm{ft}$ in April 1986 and averaged $1.76 \mathrm{ft}$. Note that September $1986 \mathrm{had}$ large absolute and arithmetic differences, which is most likely due to the above-normal rainfall that occurred. About 5.7 in. of precipitation fell during this month, which is about 3.3 in. above the normal average for September. Most of the September precipitation occurred during just two rainfall events, indicating that runoff increased (and infiltration ceased) once the surface soil became saturated. Because the model distributes the recharge at a constant rate, it cannot account for such short-term variations. Therefore, assigned recharge probably was overestimated, resulting in simulated water levels higher than those measured. Simulated and measured water levels for mid-summer of year two of the transient simulation (July 1986) are shown in table 7, and the water-table configuration for the same month is shown in figure 10 . Hydrographs showing simulated and measured water levels for five selected wells are shown in figure 11. The simulated and measured water-levels correspond favorably. Such comparisons allowed the monthly recharge factors to be adjusted during calibration. Most of the hydrographs show higher simulated water levels in September 1986 as discussed above.

The water budgets for the monthly transient simulations of 1985 and 1986 are shown in table 8. Recharge from above-normal precipitation averaged about 61 percent of all inflow to the system in 1985, and about 29 percent of inflow in 1986. Ground-water inflow from adjacent aquifers accounted for about 19 percent of all inflow during 1985 and about 10 percent in 1986 . Well discharge was a minor (less than 2 percent) outflow from the system.

As mentioned earlier, the sensitivity analysis seems to indicate that decreasing the hydraulic conductivity and/or increasing the recharge rate would improve the agreement between simulated and observed water levels. However, in practice, either of these actions will result in higher simulated water levels for steady-state conditions. Because the steadystate water levels are used as beginning heads for the antecedent simulations, which in turn are used as beginning heads for the transient simulations, higher steady-state water levels will cause the simulated water levels to be even higher than the observed water levels for the first several months of the transient simulation, as evidenced in table 3 .

\section{APPRAISAL OF THE BIG SIOUX AQUIFER USING THE DIGITAL MODEL}

The model of the Big Sioux aquifer was used as a tool to evaluate possible effects of various environmental stresses on the water levels in Lincoln and Union Counties. Stresses important to this hydrologic system include municipal, rural-water-system, and irrigation pumpage; precipitation; river stage; and evapotranspiration by plant cover.

The model was used to evaluate the effects of maximum permitted irrigation pumpage and dry conditions (decreased recharge and river stages) on water levels. The irrigation water applied to the land was assumed to be completely lost to plant uptake and evapotranspiration. In this way, irrigation pumpage would not provide any return flow to the aquifer. The results of this simulation may be used to evaluate management practices and to aid in prudent utilization of water from the Big Sioux aquifer in Lincoln and Union Counties. 
Table 7. Difference between simulated and measured water levels for July 1986

\begin{tabular}{|c|c|c|c|c|c|}
\hline Row & Column & Location of observation well & $\begin{array}{c}\text { Measured } \\
\text { water levels } \\
\text { (feet above } \\
\text { sea level) }\end{array}$ & $\begin{array}{c}\text { Simulated } \\
\text { water levels } \\
\text { (feet above } \\
\text { sea level) }\end{array}$ & $\begin{array}{c}\text { Difference } \\
\text { between simulated } \\
\text { and measured } \\
\text { water levels } \\
\text { (feet) }\end{array}$ \\
\hline 36 & 47 & 99N48W21BBAA & $1,246.00$ & $1,249.42$ & 3.42 \\
\hline 39 & 46 & 99N48W20DDDD & $1,246.60$ & $1,249.37$ & 2.77 \\
\hline 53 & 46 & 98N48W8ADDA & $1,233.60$ & $1,237.50$ & 3.90 \\
\hline 59 & 46 & 98N48W17DDCB2 & $1,237.75$ & $1,235.60$ & -2.15 \\
\hline 60 & 38 & 98N49W24AAAA & $1,237.45$ & $1,234.84$ & -2.61 \\
\hline 60 & 41 & 98N48W19ABBB & $1,241.20$ & $1,240.51$ & -0.69 \\
\hline 81 & 56 & 97N48W14BDCC & $1,198.22$ & $1,196.17$ & -2.05 \\
\hline 82 & 56 & 97N48W14CACA2 & $1,198.98$ & $1,199.43$ & 0.45 \\
\hline 84 & 57 & 97N49W23ABCA & $1,196.85$ & $1,195.87$ & -0.98 \\
\hline 85 & 57 & 97N48W23ACDB & $1,203.02$ & $1,198.21$ & -4.81 \\
\hline 87 & 55 & 97N48W23CCDD & $1,200.80$ & $1,199.34$ & -1.46 \\
\hline 88 & 58 & 97N48W26AABB & $1,193.35$ & $1,192.23$ & -1.12 \\
\hline 95 & 59 & 97N48W36CCAB & $1,189.98$ & $1,188.31$ & -1.67 \\
\hline 105 & 70 & $96 \mathrm{~N} 47 \mathrm{~W} 16 \mathrm{BCCB}$ IO & $1,198.43$ & $1,194.01$ & -4.42 \\
\hline 111 & 56 & 96N48W23CDDD & $1,202.62$ & $1,205.1,2$ & 2.50 \\
\hline 112 & 59 & 96N48W25BBAA & $1,197.20$ & $1,195.29$ & -1.91 \\
\hline 112 & 66 & 96N47W30AAAA IO & $1,184.10$ & $1,184.86$ & 0.76 \\
\hline 115 & 56 & 96N48W26CDDD & $1,196.16$ & $1,196.95$ & 0.79 \\
\hline 116 & 54 & 96N48W34AAAA & $1,203.02$ & $1,199.30$ & -3.72 \\
\hline 119 & 56 & 96N48W35CDDD & $1,193.90$ & $1,192.99$ & -0.91 \\
\hline 119 & 61 & 96N48W36DCCD & $1,176.00$ & $1,177.63$ & 1.63 \\
\hline 120 & 53 & 95N48W3ABAA & $1,198.02$ & $1,197.69$ & -0.33 \\
\hline 120 & 58 & 95N48W2AAAA & $1,188.36$ & $1,187.05$ & -1.31 \\
\hline 123 & 58 & 95N48W2DDDD & $1,185.00$ & $1,182.79$ & -2.21 \\
\hline 127 & 52 & $95 \mathrm{~N} 48 \mathrm{~W} 10 \mathrm{CDCC}$ & $1,173.52$ & $1,174.19$ & 0.67 \\
\hline 132 & 48 & 95N48W21BACA & $1,164.54$ & $1,163.87$ & -0.67 \\
\hline 133 & 51 & $95 \mathrm{~N} 48 \mathrm{~W} 22 \mathrm{BCCC}$ IO & $1,166.69$ & $1,166.74$ & 0.05 \\
\hline 133 & 54 & 95N48W22ADDD IO & $1 ., 171.21$ & $1,170.89$ & -0.32 \\
\hline
\end{tabular}


Table 7. Difference between simulated and measured water levels for July 1986—Continued

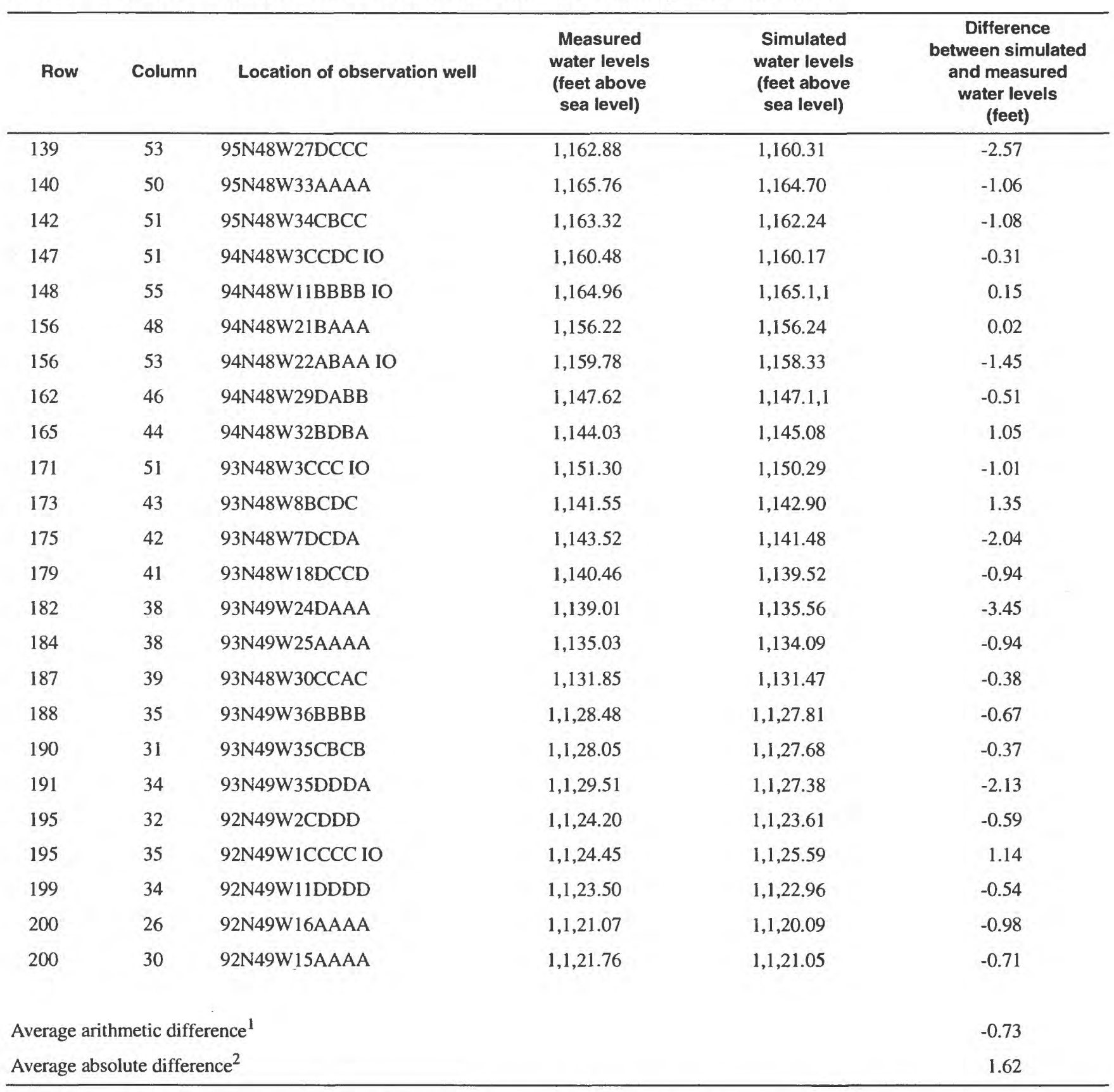

\footnotetext{
${ }^{\mathrm{I}}$ The sum of the differences between simulated and measured water levels divided by the number of observation wells measured.

${ }^{2}$ The sum of the absolute values of the differences between simulated and measured water levels divided by the number of observation wells measured.
} 


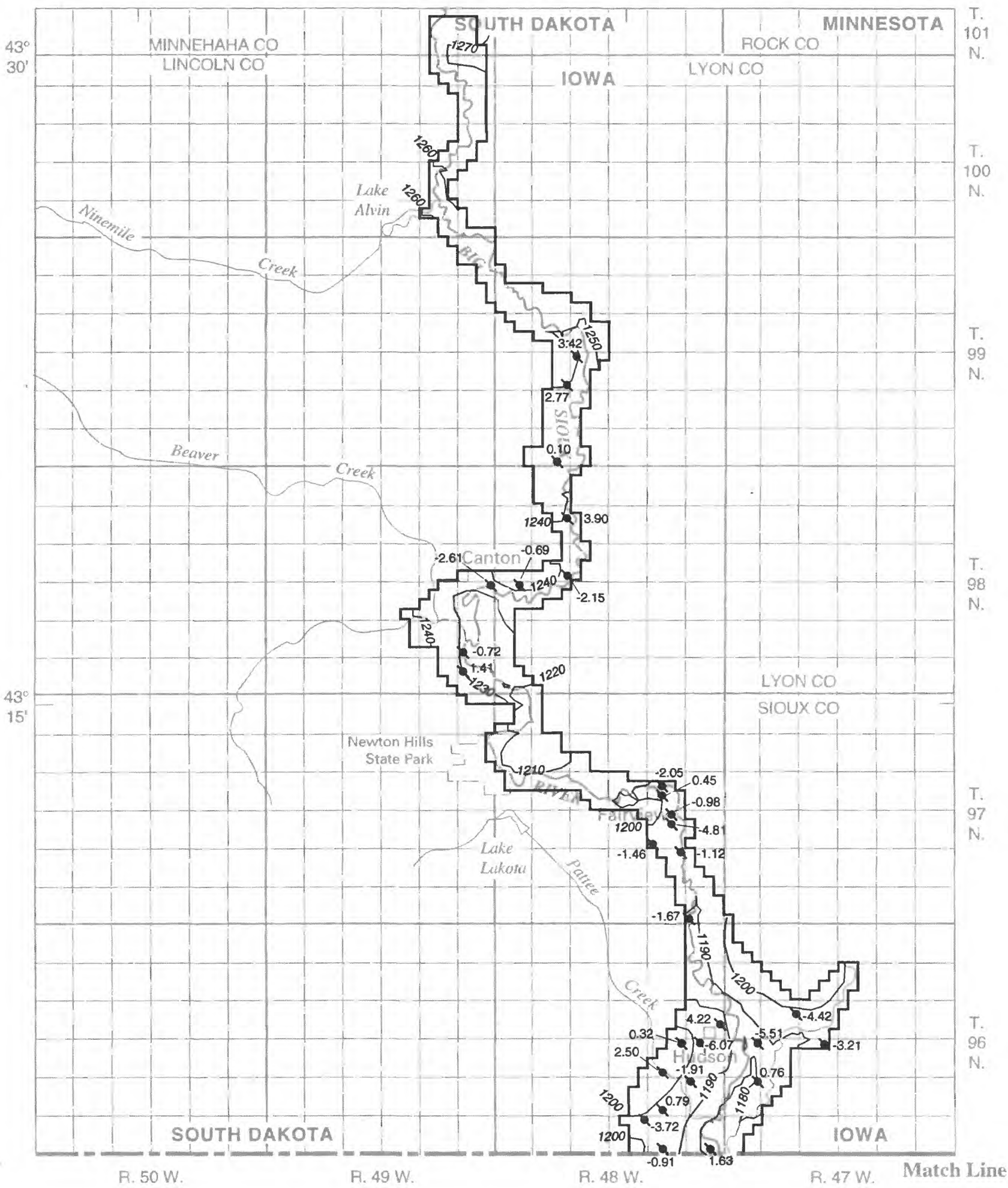

Figure 10. Simulated transient water-table configuration and differences between simulated and measured water levels at the end of July 1986. 


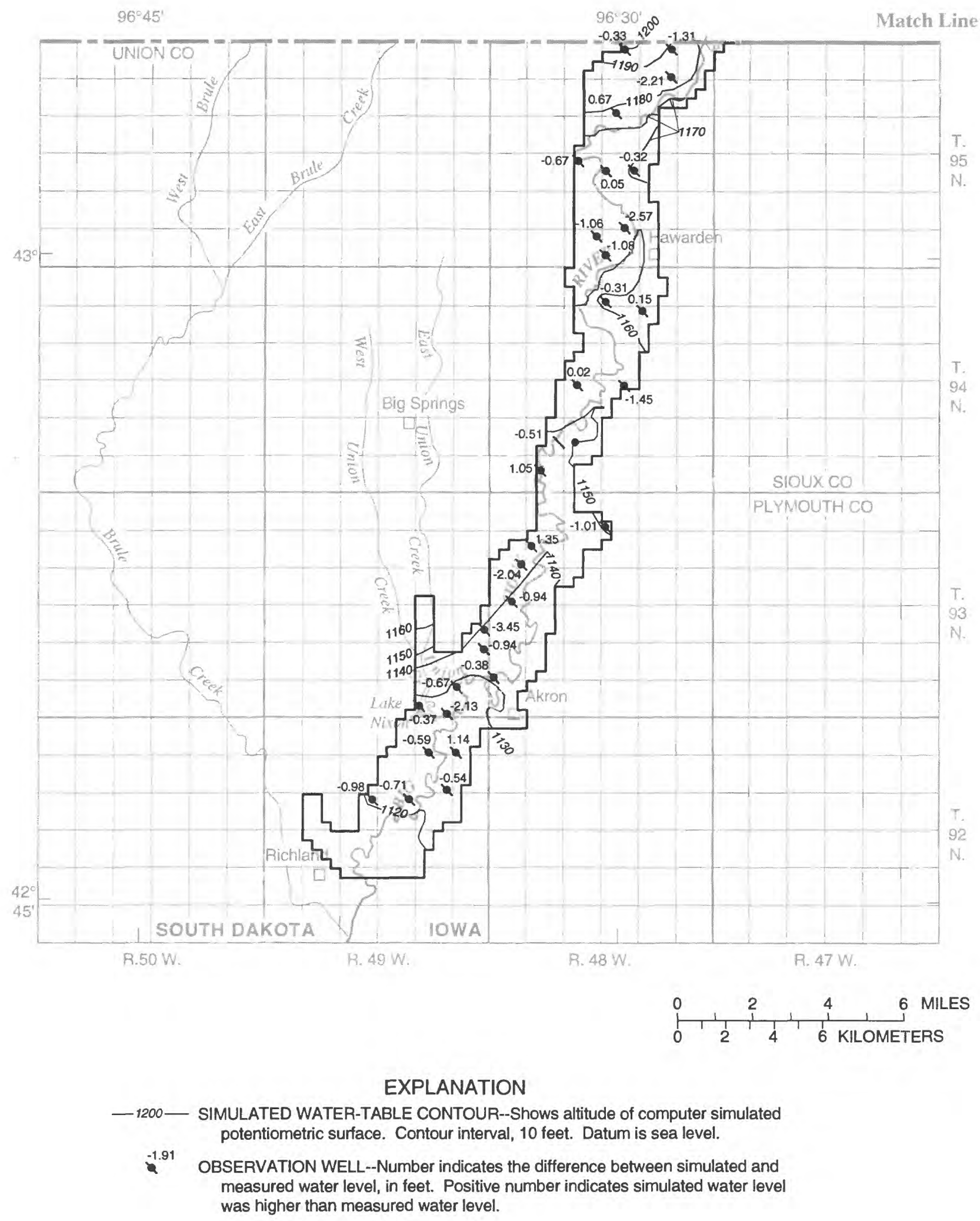

Figure 10. Simulated transient water-table configuration and differences between simulated and measured water levels at the end of July 1986.--Continued 

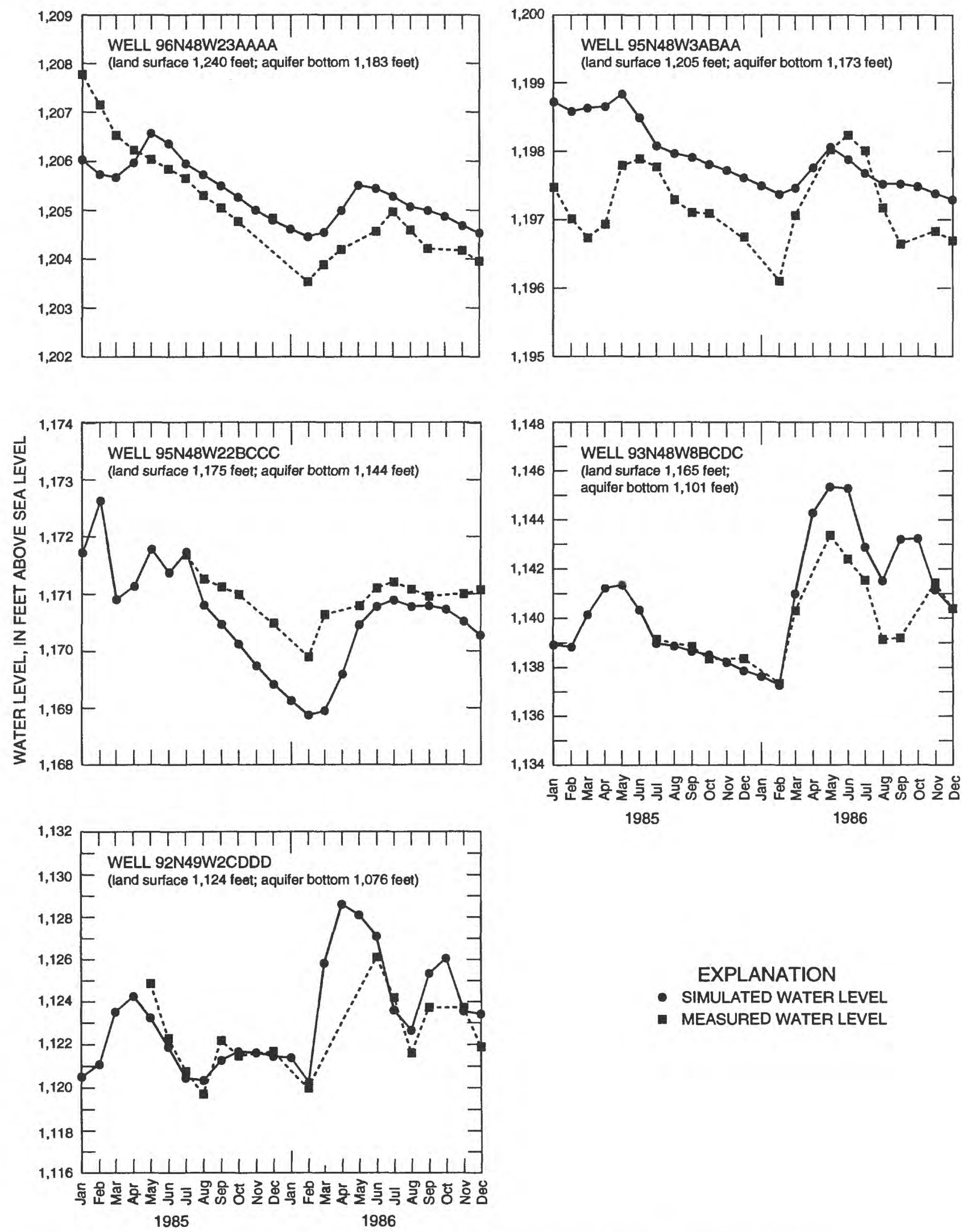

Figure 11. Hydrographs comparing simulated and measured water levels during the transient simulation. 


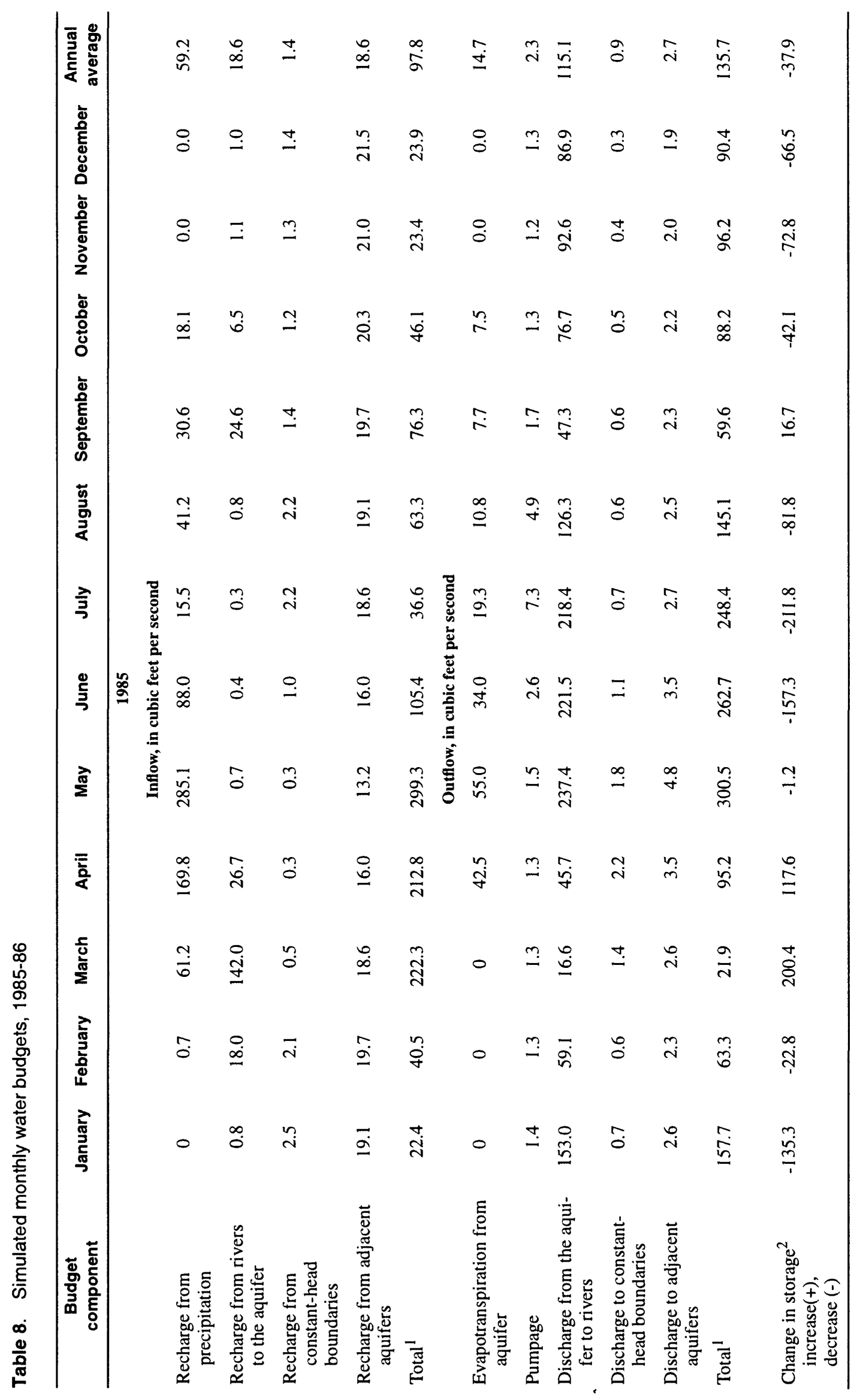




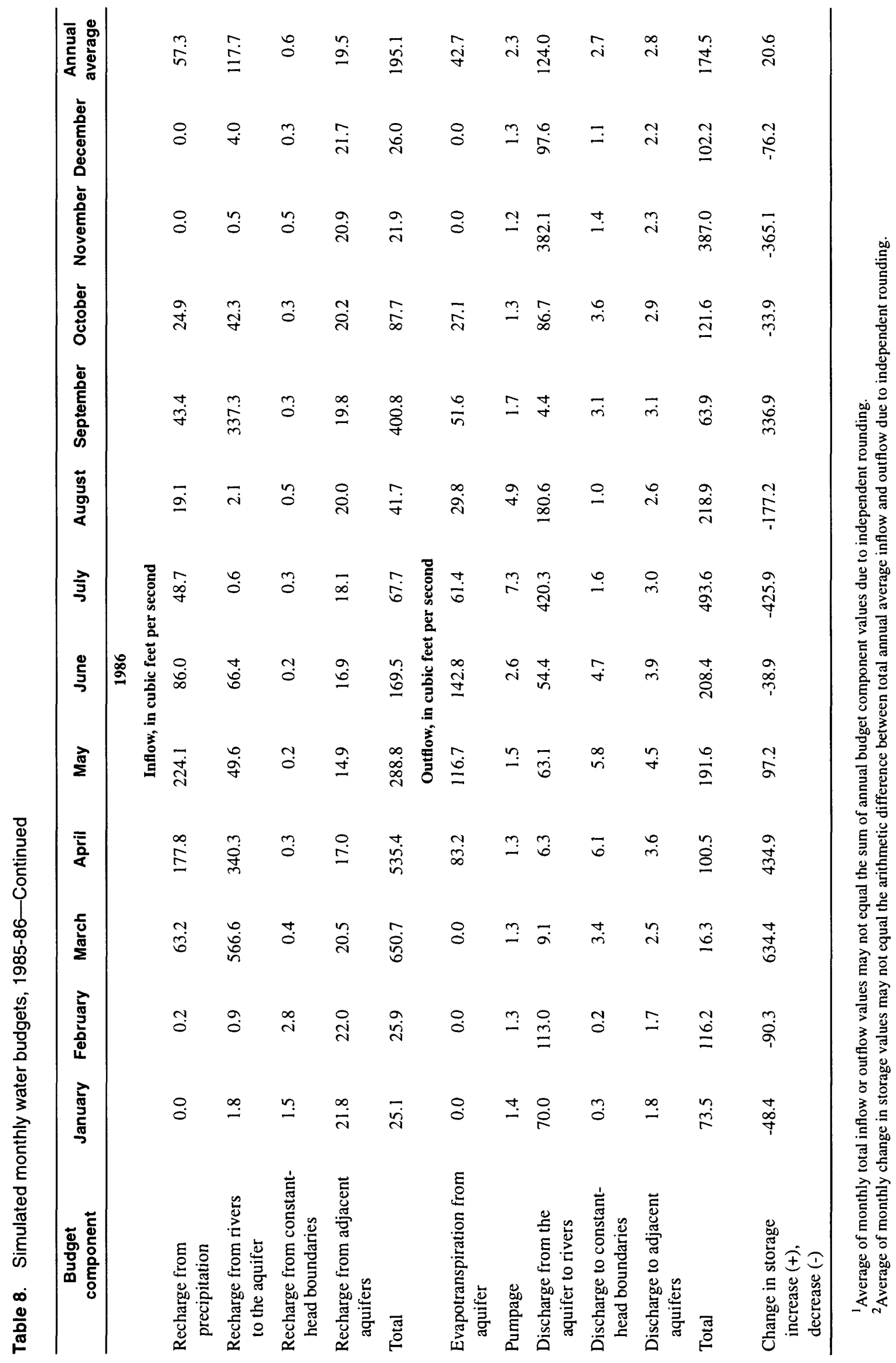

32 Appraisal of the Water Resources of the Big Sioux Aquifer, Lincoln and Union Counties, South Dakota 
A hypothetical scenario using increased irrigation pumpage was developed to ascertain the capability of the aquifer in supporting more extensive irrigation under dry conditions. Within the period used for steady-state simulation, 1988 and 1989 were two consecutive years with below-normal precipitation and river stages, and also above-normal evaporation. The recharge and evapotranspiration rates for a simulation of 1988 and 1989 conditions, except with a hypothetical increase in pumpage for irrigation (table 9) were calculated using the same procedures as for the transient simulation of 1985 and 1986 conditions. River stages were based on actual streamflow data from 1988 and 1989. Stages during these years were low due to below-normal precipitation and above-normal evaporation, but also because the antecedent year, 1987, was drier than normal. Steady-state heads were used as initial conditions for the 24-month simulation. Irrigation pumpage for the aquifer was based on maximum permitted pumping rates found in the U.S. Geological Survey State Water Use Databases (SWUDs) for South Dakota and Iowa. The 23 irrigation wells in the Big Sioux aquifer in Lincoln and Union Counties had a combined maximum permitted pumping rate of $48.15 \mathrm{ft}^{3} / \mathrm{s}$. Irrigation wells in Iowa generally had smaller maximum permitted pumping rates than those in South Dakota; the 33 wells in Iowa had a combined maximum pumping rate of $7.03 \mathrm{ft}^{3} / \mathrm{s}$.

Throughout the simulation, many cells containing irrigation wells on the South Dakota side of the Big Sioux River went dry (outflow exceeded inflow) and were converted to no-flow cells. Only one of the maximum permitted pumping rates for irrigation wells in Iowa caused a cell to go dry. The pumping rates in the affected wells were adjusted to prevent cells from converting to no flow and remaining that way for the duration of the simulation. The pumping rate was lowered iteratively to determine a pumping rate for each well and for each month that would prevent the cell from going dry. The sustainable pumpage for each month in the simulation is shown in the hydrologic budgets in table 10 . These pumping rates can be compared to the total maximum permitted irrigation pumping rate of about $55 \mathrm{ft}^{3} / \mathrm{s}$. It is important to realize that the aquifer may respond somewhat differently than the modeled system, which simulates regional responses to values of withdrawal and does not account for local well hydraulics. The simulation estimates, on a regional scale, the amount of pumping the Big Sioux aquifer could support under dry conditions and with the existing number of irrigation wells.
Table 9. Estimated monthly areal recharge and evapotranspiration for 1988 and 1989

\begin{tabular}{|c|c|c|c|}
\hline \multicolumn{2}{|c|}{ Stress period } & \multirow{2}{*}{$\begin{array}{c}\begin{array}{c}\text { Recharge rate } \\
\text { (inches) }\end{array} \\
0\end{array}$} & \multirow{2}{*}{$\begin{array}{c}\text { Evapotrans- } \\
\text { piration rate } \\
\text { (inches) }\end{array}$} \\
\hline 1988 & January & & \\
\hline & February & 0.05 & 0 \\
\hline & March & 0.21 & 0 \\
\hline & April & 1.03 & 3.62 \\
\hline & May & 1.43 & 7.57 \\
\hline & June & 0.32 & 9.46 \\
\hline & July & 0.18 & 8.77 \\
\hline & August & 0.37 & 7.93 \\
\hline & September & 0.32 & 4.81 \\
\hline & October & 0.04 & 2.22 \\
\hline & November & 0 & 0 \\
\hline & December & 0 & 0 \\
\hline \multirow[t]{12}{*}{1989} & January & 0 & 0 \\
\hline & February & 0.06 & 0 \\
\hline & March & 0.36 & 0 \\
\hline & April & 0.57 & 4.30 \\
\hline & May & 0.65 & 5.61 \\
\hline & June & 0.71 & 6.70 \\
\hline & July & 1.00 & 7.86 \\
\hline & August & 0.22 & 6.10 \\
\hline & September & 0.15 & 4.45 \\
\hline & October & 0.04 & 2.96 \\
\hline & November & 0 & 0 \\
\hline & December & 0 & 0 \\
\hline
\end{tabular}

The depletion of storage that occurs during dry conditions and increased pumpage can be observed in the hydrologic budgets of the simulation (table 10). The net average decrease in storage in 1988 was $38.9 \mathrm{ft}^{3} / \mathrm{s}$ and in 1989 was $8.6 \mathrm{ft}^{3} / \mathrm{s}$. The lesser storage depletion in 1989 likely reflects that the system is tending towards a new, lower water table in response to dry conditions. This trend is also evident in the net outflow to the river. Net outflow (outflow-inflow) to rivers was $23.0 \mathrm{ft}^{3} / \mathrm{s}$ less in 1989 , probably because the lower overall water levels in the aquifer result in a decreased gradient towards the rivers.

These simulation results indicate that the Big Sioux aquifer in Lincoln and Union Counties probably is unable to support the present maximum permitted pumping rates during extended dry periods. However, the smaller total pumping rates currently permitted in the adjacent Iowa counties of Lyon, Plymouth, and Sioux could be sustained. 


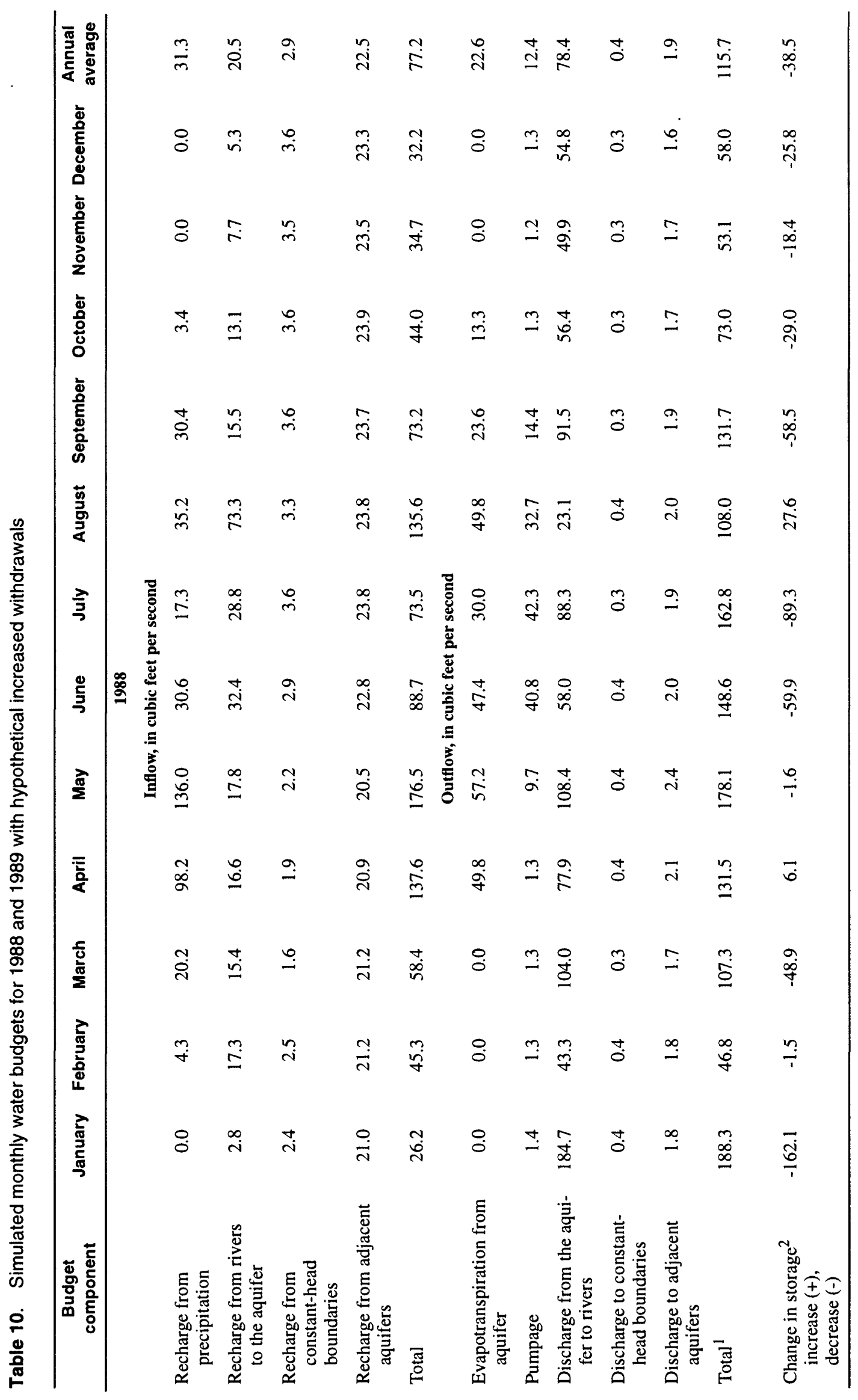




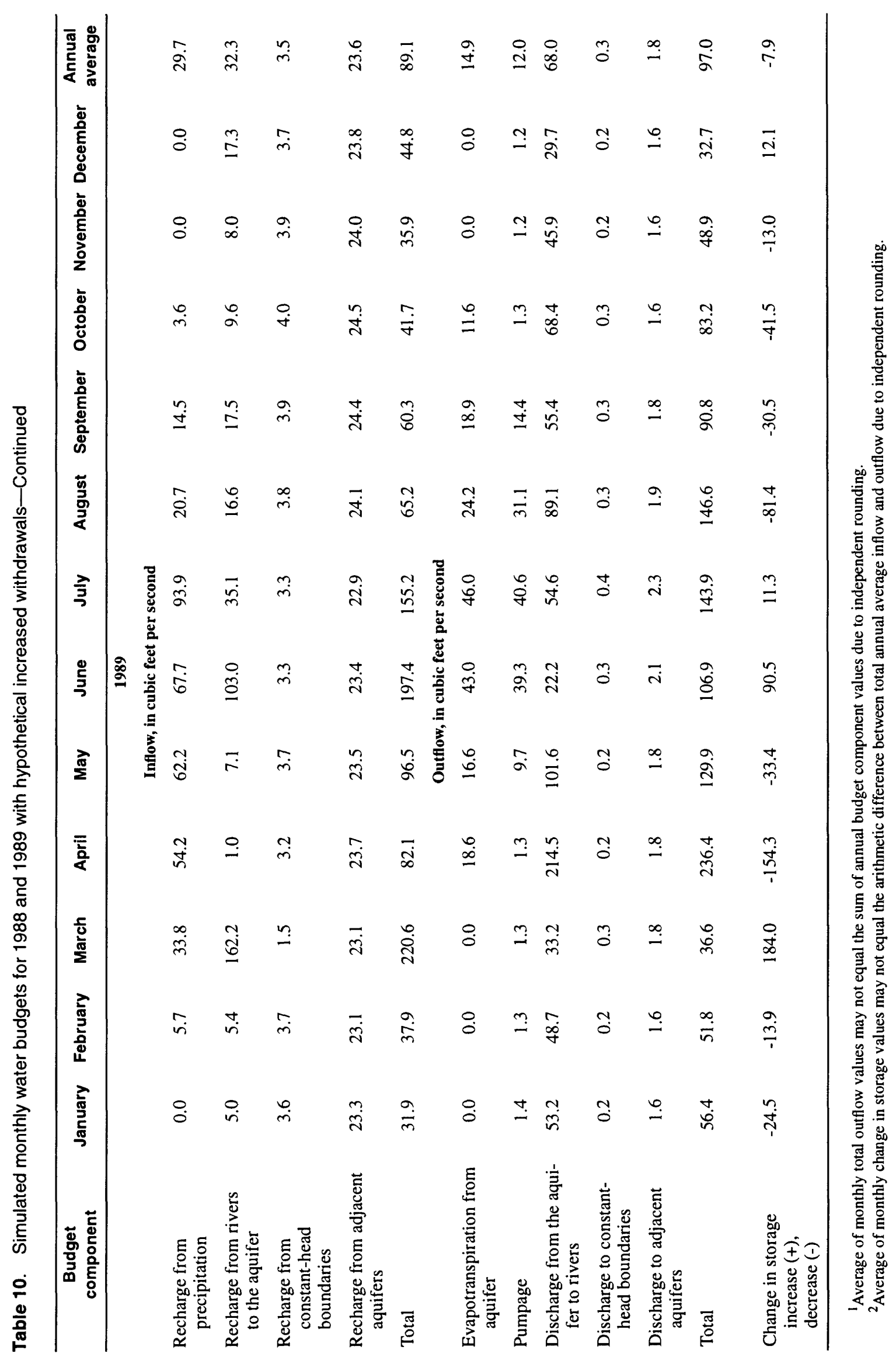




\section{SUMMARY}

The Big Sioux aquifer in Lincoln and Union Counties is a 60 -square-mile, predominantly unconfined aquifer that is hydraulically connected to the Big Sioux River and to the Shindler aquifer in northeastern Lincoln County, to the Newton Hills aquifer in southeastern Lincoln County, and to the Missouri aquifer at its extreme southern end in central Union County. Observation-well data indicate that the Big Sioux aquifer receives some leakage through sandy till from the Brule Creek aquifer in central Union County. The average thickness of the Big Sioux aquifer in Lincoln and Union Counties is 28 feet and the maximum thickness is 72 feet. The aquifer is overlain by either alluvium/colluvium or till and underlain by till or Carlile Shale.

A digital model was constructed to simulate ground-water flow in the Big Sioux aquifer in Lincoln and Union Counties. The Shindler, Newton Hills, Brule Creek, and Missouri aquifers were treated as various boundary conditions to simulate hydraulic connections to the Big Sioux aquifer. The model was calibrated to simulate both steady-state (1976-94) and transient (1985 and 1986) conditions. The model was calibrated for steady-state conditions using average annual water levels of the Big Sioux aquifer, recharge, evapotranspiration, well pumpage, river stages, and base-flow discharge in the Big Sioux River. Steadystate simulated water levels for the Big Sioux aquifer from 57 observation wells averaged 0.91 foot lower than measured water levels. The average absolute difference between simulated and measured water levels was 1.54 feet.

Sensitivity analyses of the steady-state model indicated that the recharge rate and aquifer hydraulic conductivity had the greatest effect on simulated water levels. The evapotranspiration extinction depth and evapotranspiration rate had the least effect on simulated water levels.

The model was calibrated for transient conditions using 1985 and 1986 ground-water levels. Measured observation-well water levels were compared to simulated water levels in the Big Sioux aquifer in as many as 62 wells on a monthly basis. The average monthly difference between simulated and measured water levels was -0.15 foot. The absolute value of the average monthly difference between simulated and measured water levels was 1.76 feet.

A hypothetical simulation using dryer than normal conditions and maximum permitted irrigation pumpage revealed that the Big Sioux aquifer in Lincoln and Union Counties in South Dakota was unable to support continuous pumpage when simulated at the current permitted irrigation levels.

\section{REFERENCES}

Amundson, F.D., Bradford, Wendell, and Koch, N.C., 1985, Drainage areas in the Big Sioux River Basin in eastern South Dakota: U.S. Geological Survey Open-File Report 85-348, 1 sheet.

Benson, R.D., Freese, M.E., and Amundson, F.D., 1988, Drainage areas in the Vermillion River Basin in eastern South Dakota: U.S. Geological Survey Open-File Report 88-720, 1 sheet.

Christensen, C.M., and Stephens, J.C., 1967, Geology and hydrology of Clay County, South Dakota, Part I: Geology: South Dakota Geological Survey Bulletin 19, $86 \mathrm{p}$.

Eagleman, J.R., 1967, Pan evaporation, potential and actual evapotranspiration: Journal of Applied Meteorology, v. 6, no. 3, p. 482-488.

Ellis, M.J., and Adolphson, D.G., 1969, Basic hydrologic data, for a part of the Big Sioux drainage basin, eastern South Dakota: South Dakota Geological Survey and South Dakota Water Resources Commission, Water Resources Report 5, 124 p.

Hammond, P.D., 1989, Investigation of the extent and ground-water quality of the Dakota Formation near Lennox, South Dakota: South Dakota Geological Survey Open-File Report 56-UR, 33 p.

Hansen, D.S., 1988, Appraisal of the water resources of the Big Sioux aquifer, Moody County, South Dakota: U.S. Geological Survey Water-Resources Investigations Report 87-4057, 38 p.

1990, Water resources of Codington and Grant Counties, South Dakota: U.S. Geological Survey Water-Resources Investigations Report 89-4147, 47 p.

Iles, D.L., 1979, Ground-water study for southern Union County: South Dakota Geological Survey Open File Report 28-UR, 63 p.

Jarrett, M.J., 1986, Sand and gravel resources in Turner County, South Dakota: South Dakota Geological Survey Information Pamphlet No. 34, 70 p.

- 1988, Sand and gravel resources in Union County, South Dakota: South Dakota Geological Survey Information Pamphlet No. 38, 56 p.

Jones, O.R., and Schneider, A.D., 1969, Determining specific yield of the Ogallala aquifer by the neutron method: Water Resources Research, v. 5, no. 6, p. 1267-1272. 
Jorgensen, D.G., and Ackroyd, E.A., 1973, Water resources of the Big Sioux River valley near Sioux Falls, South Dakota: U.S. Geological Survey Water-Supply Paper 2024, 50 p.

Koch, N.C., 1980, Appraisal of the water resources of the Big Sioux aquifer, Brookings, Deuel, and Hamlin Counties, South Dakota: U.S. Geological Survey Water-Resources Investigations Report 80-100, 46 p. 1982, A digital-computer model of the Big Sioux aquifer in Minnehaha County, South Dakota: U.S. Geological Survey Water-Resources Investigations 82-4064, 49 p.

Lindgren, R.J., and Hansen, D.S., 1990, Water resources of Hutchinson and Turner Counties, South Dakota: U.S. Geological Survey Water-Resources Investigations Report 90-4093, 100 p.

1993, Major aquifers in Hutchinson and Turner Counties, South Dakota: South Dakota Geological Survey Information Pamphlet No. 45, 12 p.

Lindgren, R.J., and Niehus, C.A., 1992, Water resources of Minnehaha County, South Dakota: U.S. Geological Survey Water-Resources Investigations Report 91-4101, 80 p.

McDonald, M.G., and Harbaugh, A.W., 1988, A modular three-dimensional finite-difference ground-water flow model: U.S. Geological Survey Open-File Report 83-875, $528 \mathrm{p}$.

Meyer, W.L., 1962, Use of a neutron moisture probe to determine the storage coefficient of an unconfined aquifer: U.S. Geological Survey Water Supply Paper 450-E, p. E174-E176.

National Oceanic and Atmospheric Administration, 1976-94, Climatological data for South Dakota (issued annually). 1982a, Mean monthly, seasonal, and annual pan evaporation for the United States: Technical Report 34. 1982b, Evaporation atlas for the contiguous United States: Technical Report 33.

Niehus, C.A., 1994, Water resources of Lincoln and Union Counties, South Dakota: U.S. Geological Survey Water-Resources Investigations Report 93-4195, $57 \mathrm{p}$. 1997, Major aquifers in Lincoln and Union Counties, South Dakota: South Dakota Geological Survey Information Pamphlet No. 49, 26 p.

Ohland, G.L., 1990, Appraisal of the water resources of the Skunk Creek aquifer in Minnehaha County, South Dakota: U.S. Geological Survey Water-Resources Investigations Report 87-4156, 54 p.

Putnam, L.D., and Thompson, R.C., 1996, Appraisal of the water resources of the Big Sioux aquifer, Codington and Grant Counties, South Dakota: U.S. Geological Survey Water-Resources Investigations Report 96-4275, 34 p.

Schulz, L.D., and Jarrett, M.J., 1991, Sand and gravel resources in Lincoln County, South Dakota: South Dakota Geological Survey Information Pamphlet No. 43,48 p.

Tomhave, D.W., 1994, Geology of Minnehaha County, South Dakota: South Dakota Geological Survey Bulletin 37, 53 p.

U.S. Geological Survey, 1977-95a, Water resources data for South Dakota, water years 1976-94: U.S. Geological Survey Water-Data Reports SD-76-1 to SD-94-1 (published annually).

1977-95b, Water resources data for Iowa, water years 1976-94: U.S. Geological Survey Water-Data Reports IA-76-1 to IA-94-1 (published annually). 